\title{
Glacial stages and post-glacial environmental evolution in the Upper Garonne valley, Central Pyrenees
}

\author{
M. Fernandes ${ }^{\mathrm{a}, *}$, M. Oliva a ${ }^{\text {a P. Palma }}{ }^{\text {a }}$, J. Ruiz-Fernández ${ }^{\mathrm{b}}$, L. Lopes ${ }^{\text {a }}$ \\ ${ }^{a}$ Centre for Geographical Studies - IGOT, Universidade de Lisboa, Lisbon, Portugal \\ b Department of Geography, University of Oviedo, Oviedo, Spain
}

\section{H I G H L I G H T S}

- We examine glacial and post-glacial environmental stages in the Upper Garonne.

- Four glacial stages have been inferred since the local last glacial maximum.

- The maximum ice extent formed a piedmont glacier $88.7 \mathrm{~km}$ long covering $693 \mathrm{~km}^{2}$.

- Next glacial stages formed smaller valley glaciers followed by cirque glaciers.

- Present environmental dynamics is organized in: subnival, nival, periglacial belts.

\section{G R A P H I C A L A B S T R A C T}

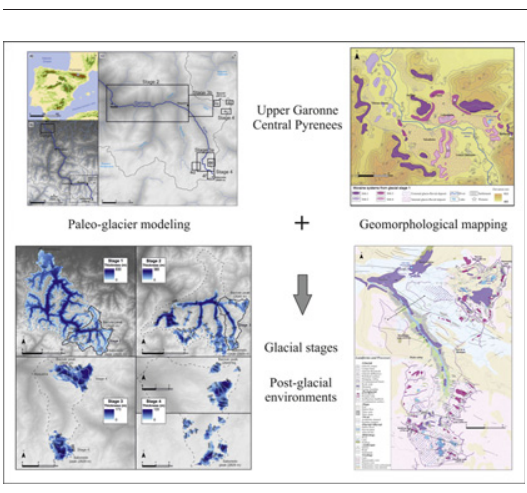

\section{A R T I C L E I N F O}

\section{Article history:}

Received 7 November 2016

Received in revised form 15 January 2017

Accepted 27 January 2017

Available online 3 February 2017

Editor: D. Barcelo

Keywords:

Central Pyrenees

Upper Garonne

Last Glaciation

Deglaciation

Holocene

Geomorphology

\begin{abstract}
A B S T R A C T
The maximum glacial extent in the Central Pyrenees during the Last Glaciation is known to have occurred before the global Last Glacial Maximum, but the succession of cold events afterwards and their impact on the landscape are still relatively unknown. This study focuses on the environmental evolution in the upper valley of the Garonne River since the Last Glaciation. Geomorphological mapping allows analysis of the spatial distribution of inherited and current processes and landforms in the study area. The distribution of glacial records (moraines, till, erratic boulders, glacial thresholds) suggests the existence of four glacial stages, from the maximum expansion to the end of the glaciation. GIS modeling allows quantification of the Equilibrium Line Altitude, extent, thickness and volume of ice in each glacial stage. During the first stage, the Garonne glacier reached $460 \mathrm{~m}$ in the Loures-Barousse-Barbazan basin, where it formed a piedmont glacier $88 \mathrm{~km}$ from the head and extended over $960 \mathrm{~km}^{2}$. At a second stage of glacier stabilization during the deglaciation process, the valley glaciers were $12-23 \mathrm{~km}$ from the head until elevations of $1000-1850 \mathrm{~m}$, covering an area of $157 \mathrm{~km}^{2}$. Glaciers during stage three remained isolated in the upper parts of the valley, at heights of 2050-2200 m and 2.6-4.5 km from the head, with a glacial surface of $16 \mathrm{~km}^{2}$. In stage four, cirque glaciers were formed between $2260 \mathrm{~m}$ and $2590 \mathrm{~m}$, with a length of $0.4-2 \mathrm{~km}$ and a glacial area of $5.7 \mathrm{~km}^{2}$. Also, the wide range of periglacial, slope, nival and alluvial landforms existing in the formerly glaciated environments allows reconstruction of the post-glacial environmental dynamics in the upper Garonne basin. Today, the highest lands are organized following three elevation belts: subnival (1500-1900 m), nival (1900-2300 m) and periglacial/cryonival (2300-2800 m).
\end{abstract}

(C) 2017 Elsevier B.V. All rights reserved.

\footnotetext{
* Corresponding author at: Centre for Geographical Studies - IGOT, Universidade de Lisboa, Rua Branca Edmée Marques - Edifício do IGOT, $1600-276$ Lisboa, Portugal. E-mail address: marcelo.fernandes@live.com (M. Fernandes).
} 


\section{Introduction}

In recent years, knowledge about the maximum glacial extent in the Pyrenees has gained consistency, as well as its chronology, which has been redefined. However, the post-glacial environmental evolution during the deglaciation and the Holocene is still relatively unknown (Delmas, 2015). The local Maximum Ice Extent (MIE) of the Last Glaciation in the Iberian mountains shows a different spatio-temporal pattern among the ranges in the north-northwest, those in the south and the rest of the peninsula (Hughes and Woodward, 2008). The Pyrenees was the mountain system with the greatest glacial extent in the whole Iberian Peninsula (Pérez-Alberti et al., 2004), where glacial evidence suggests an attenuated and asynchronous response to global forcings due to latitudinal and transitional conditions between the Atlantic Ocean and the Mediterranean Sea (Turu et al., 2016).

The first studies on Pleistocene glaciation in the Pyrenees emerged at the end of the 19th century (Penck, 1883). Knowledge about its chronology and the distinct glacial phases increased gradually in the second half of the 20th century, through geomorphological analyses and the first radiocarbon dates (García-Ruiz et al., 2010). These studies were recently complemented by other techniques of absolute dating - namely OSL and cosmogenic exposure dating - which established the MIE during the MIS (Marine Isotope Stage)-4, with an almost synchronic advance during the global Last Glacial Maximum (LGM) (García-Ruiz et al., 2003, 2013; Peña-Monné et al., 2003; Pallàs et al., 2006; Lewis et al., 2009; Delmas et al., 2011; García-Ruiz and Martí-Bono, 2011; Jiménez-Sánchez et al., 2013; Stange et al., 2014; Delmas, 2015; Palacios et al., 2015a, 2015b; Turu et al., 2016) but with substantial chronological differences at a regional scale (Calvet et al., 2011). In recent years, research has focused on the sequence of deglaciation, including the different stages of glacial expansion during the transition to the Holocene, namely the Oldest and Younger Dryas (Pallàs et al., 2010; Palacios et al., 2015a, 2015b, 2016b; García-Ruiz et al., 2016).

In the central area of our research, the upper valley of the Garonne River (Central Pyrenees), the first work on the impact of Late Pleistocene glaciation on the current landscape began in the middle of the 20th century, essentially on the French side (Goron, 1941; Taillefer, 1954, 1957, 1969; Kleinsmiede, 1960; Hubschman, 1984). In the Loures-Barousse-Barbazan basin, the identification, distribution and sediment characterization of the moraine systems, fluvioglacial terraces and till provided relative ages for the genesis of glacial deposits (Taillefer, 1954; Hubschman, 1975; Taillefer, 1984). Later, three moraine systems existing at the foot of the basin were attributed to the Last Glaciation, with proposed ages inferred from the sedimentary sequence of Lake Barbazan (Andrieu et al., 1988; Andrieu, 1991): (i) the outermost moraine developed during the MIE ( $>29.5-$ $33.8 \mathrm{ka}$ cal BP); (ii) a complex moraine system, with frontal moraines contemporary to the global LGM; (iii) the last one attributed to a pulsation already within the deglaciation stage. Finally, Stange et al. (2014) distinguished the moraine systems present in the area according to their degradation, morphology and distribution, and suggested that the external complex corresponded to the MIS- 4 and the internal one to the MIS-2.

The first research conducted in the upper Garonne basin, in the Val d'Aran district, dates back from the middle of the 20th century and characterized generically the main existing glacial forms in the area (Mianes, 1955; Kleinsmiede, 1960). This approach was subsequently completed with a more detailed description of the landforms and deposits through an analysis of aerial photography and fieldwork on the tributaries of the Joeu and Nere (Bordonau, 1985), Unhòla, Vadarrós and Toran (Martí-Soler, 1988). According to the distribution of erratic boulders, Vilaplana et al. (1986) and Bordonau (1992) estimated in very general terms ice-thickness distribution during the MIE.
Within this context, the objective of this study is to analyze the environmental dynamics in the upper Garonne valley from the Last Glaciation to the present day, dealing with specific matters such as:

(i) Integrating, from a geomorphological and paleo-environmental point of view, the glacial and periglacial evidence corresponding to the Last Glaciation and post-glacial evolution until today.

(ii) Inferring the sequence of phases of glacial retreat, and quantifying the extent, thickness and volume of the paleo-glaciers for each phase, as well as the corresponding Equilibrium Line Altitude (ELA).

(iii) Comparing the chronological time frame and the geomorphological evidence identified in other valleys of the Pyrenees with the different stages inferred in the upper Garonne valley and its subsequent environmental evolution.

\section{Study area}

This research is centered on the impact of glaciation on the current landscape of the upper Garonne basin and the subsequent geomorphological evolution of its highest parts, namely the Ruda valley and the Beret plateau. The upper Garonne basin is located at latitude $42-43^{\circ} \mathrm{N}$ and longitude $0-1^{\circ}$ E. Situated on the north-facing slope of the Central Pyrenees, the basin covers an area of $1260 \mathrm{~km}^{2}$ to the south of Montréjeau, on the lower slopes of the mountain range at an altitude of 450-500 m (Fig. 1). On its path towards the Bay of Biscay, in the upper part of the basin, the Garonne River receives the waters of numerous tributaries (Ruda, Valarties, Aiguamòg, Nere, Joeu, Unhòla, Varradós). The Ruda valley is at the southern head of the upper valley of the Garonne and covers an area of $34 \mathrm{~km}^{2}$. The lower part of the valley, where the Ruda River meets the Garonne, is situated at $1500 \mathrm{~m}$ and the highest parts reach $2829 \mathrm{~m}$ at the Tuc de Saboredo. The Ruda valley is a U-shaped glacial valley formed by glacial processes and structurally oriented S-N, with a rotation that ends in the E-W direction in the sector between Baquèira and Vielha (Fig. 1). The Beret plateau is a relatively horizontal area of $5 \mathrm{~km}^{2}$ of alpine meadow between 1790 and $1900 \mathrm{~m}$ containing the source of the Garonne and Noguera Pallaresa rivers. During the Last Glaciation, the glaciers descending from the Bacivèr massif left a complex moraine sequence and till spread over the plateau (Fig. 1).

The head of the basin is located on the central axis of the Pyrenees, with a W-E orientation and with peaks reaching $3000 \mathrm{~m}$ asl. In the lower part of the basin, namely in the basin of Loures-BarousseBarbazan, limestone outcrops appear on the small hills surrounding the basin filled by Quaternary deposits. In the highest parts of the valley, corresponding to the glacial valleys of the Val d'Aran, intrusive igneous materials (granites) appear near the heads whereas the lower areas are composed of detrital (slates, conglomerates and sandstone) and carbonated (limestone) sedimentary rocks (Kleinsmiede, 1960).

The Pyrenees act as a climatic boundary between environments with Atlantic or Mediterranean climatic influence. The barrier effect of this mountain range limits the effects of moist and fresh Atlantic air masses to the East. On the north-facing side of the Central Pyrenees precipitation is abundant and distributed relatively evenly throughout the year, reaching annual precipitations of $900 \mathrm{~mm}$ at Vielha (980 m), which increases with height to $1232 \mathrm{~mm}$ at Port de la Bonaigua (2266 m), at the southernmost part of the study area (Fig. 1). For the climatic period 1961-1990, the mean annual temperature at Vielha was $9.6{ }^{\circ} \mathrm{C}$ and at Port de la Bonaigua, $2.7^{\circ} \mathrm{C}$, with winter averages of $-4{ }^{\circ} \mathrm{C}$ and absolute minimums reaching $-22.5^{\circ} \mathrm{C}$ (Martín-Vide et al., 2011). Assuming a current air temperature lapse rate in the Central Pyrenees of $0.6{ }^{\circ} \mathrm{C}$ $100 \mathrm{~m}^{-1}$ (García-Ruiz et al., 2015), the $0{ }^{\circ} \mathrm{C}$ isotherm in the study area is located around $2716 \mathrm{~m}$.

The study area presents vegetation characteristic of the Euro-Siberian biogeographical region, with flat-leaf, deciduous woods in the lower 


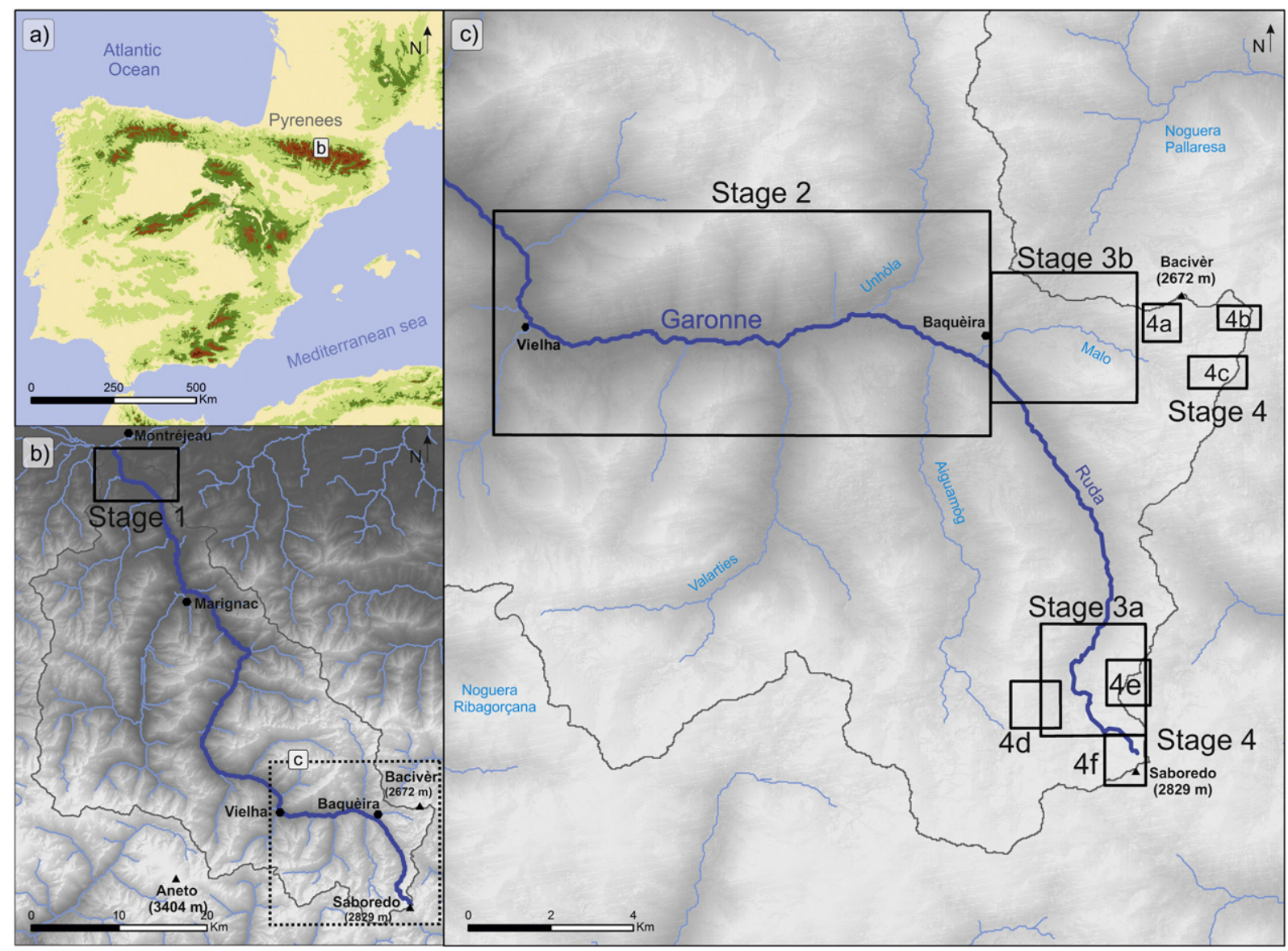

Fig. 1. Location of the Upper Garonne basin within the Iberian Peninsula.

parts and typical woods of the Boreoalpine region in the highest areas, with conifers and alpine meadows (Bolòs and Vigo, 1984).

As in other Iberian mountains such as in Sierra Nevada (Gómez-Ortiz et al., 2013) and Cantabrian Mountains (Ruiz-Fernández et al., 2016a, 2016b), the current landscape in the Central Pyrenees has been also influenced by historical human activities, which have changed the natural distribution of forests through fires to promote agricultural and grazing practices from the Mid-Holocene (Pérez-Sanz et al., 2013). The associated land use shifts have also favored changes on hydrologic and erosion processes (Lasanta et al., 2006; Serrano-Muela et al., 2008) with enhanced solifluction activity (Höllermann, 1985). In areas where the relief was more favorable to establishing these activities - low parts of the valley bottoms and high parts of the slopes -, there is still alpine meadow vegetation that has not reached the state of woodland (García-Ruiz et al., 2015).

\section{Methodology}

\subsection{Geomorphological mapping}

Analysis of the distribution of geomorphological landforms and sedimentary deposits allows reconstruction of the ice extent during the different glacial stages and post-glacial environmental evolution. The resulting geomorphological map followed the French school methodology (Joly, 1997) and was subsequently edited in a GIS environment. Two types of maps were elaborated using orthophotomaps and topographical maps supplied by the Institut Cartogràfic de Catalunya: i) a map of moraine complexes (scale 1:5000) associated with the main water course of the Garonne River, also including the complexes already catalogued at the end of the studied basin (Goron, 1941; Taillefer, 1954; Hubschman, 1975; Andrieu et al., 1988; Serrat et al., 1994; Stange et al., 2014); ii) a detailed geomorphological map (scale 1:5000) of the high parts of the basin, namely of the Ruda valley and the Beret plateau. Later, these maps were validated and complemented with field observations.

\subsection{Paleo-glacier modeling and ELAs reconstruction}

Construction of the models of the glacier extent for each of the various glacial stages identified from geomorphological observations was carried out in a GIS environment using the GlaRe tool (Pellitero et al., 2016). The methodological procedures of this tool consist in four main steps: a) creation of flowlines based on the talwegs of the valleys; b) input of a basal shear stress value according to the standard referenced value used for the glaciers valleys $(100 \mathrm{kPa})$ and for non-constrained glacier (50 kPa) (Pellitero et al., 2016); c) calculation of flowline ice thickness using a digital elevation model (Advanced Spaceborne Thermal Emission and Reflection Radiometer - ASTER - resolution $30 \mathrm{~m}$ ) and the outputs of the previous steps; d) creation of the glacier surface through the topo to raster interpolation method and using the digital elevation model, plus a tool to generate extra ice thickness points and a glacier constraint area, defined based on existing glacial landforms as the frontal and lateral moraines. The result obtained is a surface corresponding to the area of the glacier, which also allows calculation of the thickness and volume of the ice for each glacial stage. The ELAs were calculated in a GIS environment using the ELA calculation toolbox (Pellitero et al., 2015). 


\section{Glacial stages since the Last Glaciation}

The distribution of the different moraine systems in the upper Garonne basin suggests the existence of various glacial stages since the Last Glaciation:

\subsection{Glacial stage 1}

The outermost moraine system is found in the transition between the Pyrenees mountain range and Aquitaine, in the Loures-BarousseBarbazan basin. This is a basin limited by small mountains reaching $800 \mathrm{~m}$ and losing altitude as they become more distant from the foothills of the Pyrenees. It contains scattered fluvial and glacial sediments (till) frequently covered by areas of discontinuous Atlantic forest. Throughout the whole basin, elongated small hills corresponding to moraines stand out. These terminal moraines were previously identified by different authors (Goron, 1941; Taillefer, 1954, 1984; Hubschman, 1975; Andrieu et al., 1988; Andrieu, 1991; Stange et al., 2014) and are complemented here by our observations (Fig. 2). Four moraine systems are identifiable in the Loures-Barousse-Barbazan basin (Fig. 3):

\subsubsection{Moraine system 1 (MS-1)}

Moraines are found on the slopes of the mountains approximately $200 \mathrm{~m}$ above the basin floor at heights of 520-640 m. In the western part several moraine steps are identified on the slopes with erratic boulders of metric dimensions, and in the eastern part moraine ridges with angular and sub-angular blocks of different lithologies (limestones, and some granites and slates as well) with a major axis of $2 \mathrm{~m}$. Both sectors were interpreted as lateral moraines (Fig. 2).

\subsubsection{Moraine system 2 (MS-2)}

This system is defined by various moraine arches located in the outermost sector of the basin floor at $460-490 \mathrm{~m}$. The moraines are composed of heterogeneous blocks of metric dimensions. They are characterized by discontinuous, elongated formations perpendicular to the glacial flow in the western part of the basin, with the outer ones being the largest. The system was interpreted as a frontal system (Fig. 2).

\subsubsection{Moraine system 3 (MS-3)}

To this moraine system already identified by Stange et al. (2014), we add more observations of glacial features on the eastern slope of the basin (Fig. 3). The distribution of moraine ridges is restricted to the internal part of the basin, essentially on the lower slopes of the outermost hillsides but also at their foot (e.g., La Serre), at elevations of 465-540 m. On the lower slopes there are erratic boulders of metric dimensions and different lithologies (slates, granites and limestones), with various outcrops showing the glacial origin of the material composed of blocks in a sandy matrix. These deposits were interpreted as lateral moraines. The frontal moraine of La Serre, elongated and perpendicular to the glacial flow, shows a central axis folded in a downstream direction and contains few angular blocks with a major axis of $50-70 \mathrm{~cm}$ and different lithologies (Fig. 2).

\subsubsection{Moraine system 4 (MS-4)}

In the innermost part of the basin, a moraine system was identified, composed of two moraine ridges at $4 \mathrm{~km}$ from the terminal glacial complex, at heights of $470-480 \mathrm{~m}$. These moraines, perpendicular to the glacial flow, are formed of few angular blocks in a fine matrix and were defined as frontal moraines left by the glacier in its retreat (Figs. 2, 3).

\subsection{Glacial stage 2}

Glacial stage 2 developed in the main valley of the Garonne basin, in the Val d'Aran district, between the towns of Vielha and Baquèira. There it is possible to identify lateral and lateral-frontal moraines, erratic boulders and till distributed across the valley floor (Fig. 4). Deposits of glacial a)

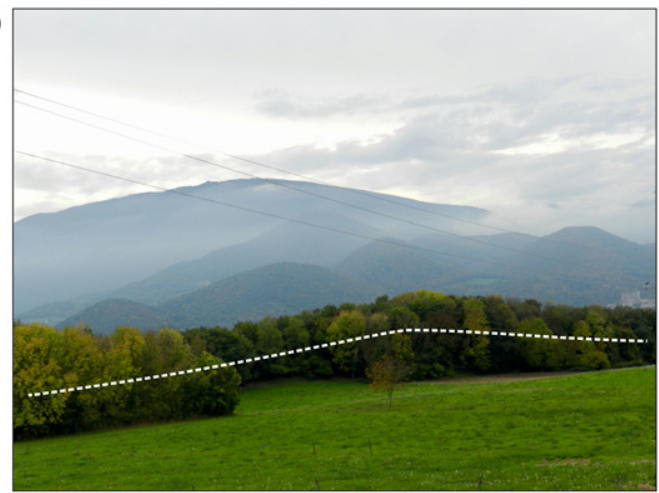

c)

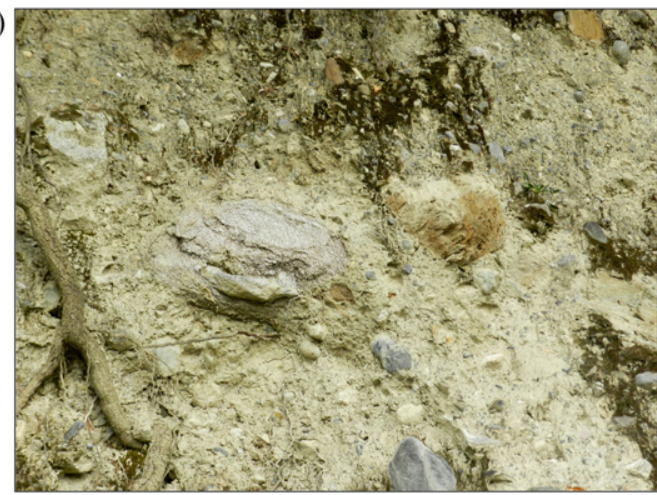

b)

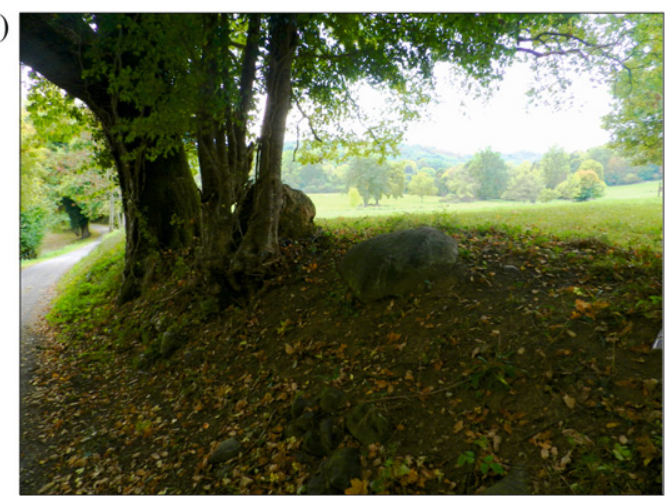

d)

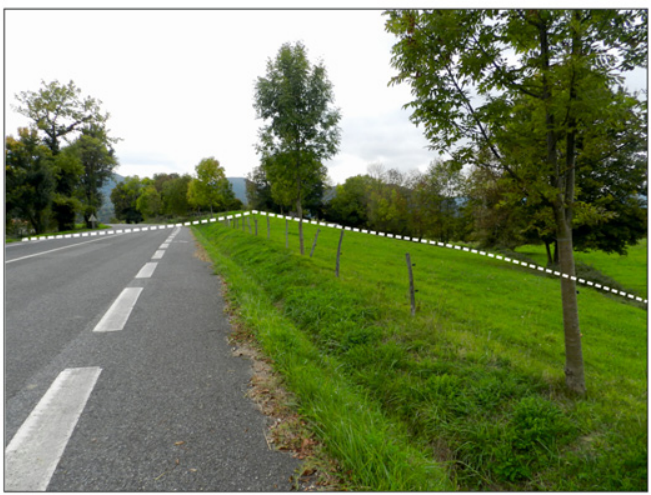

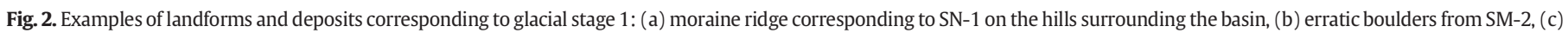
angular blocks in a sandy matrix from SM-3, and (d) moraine ridge from SM-4 in the innermost part of the basin. 


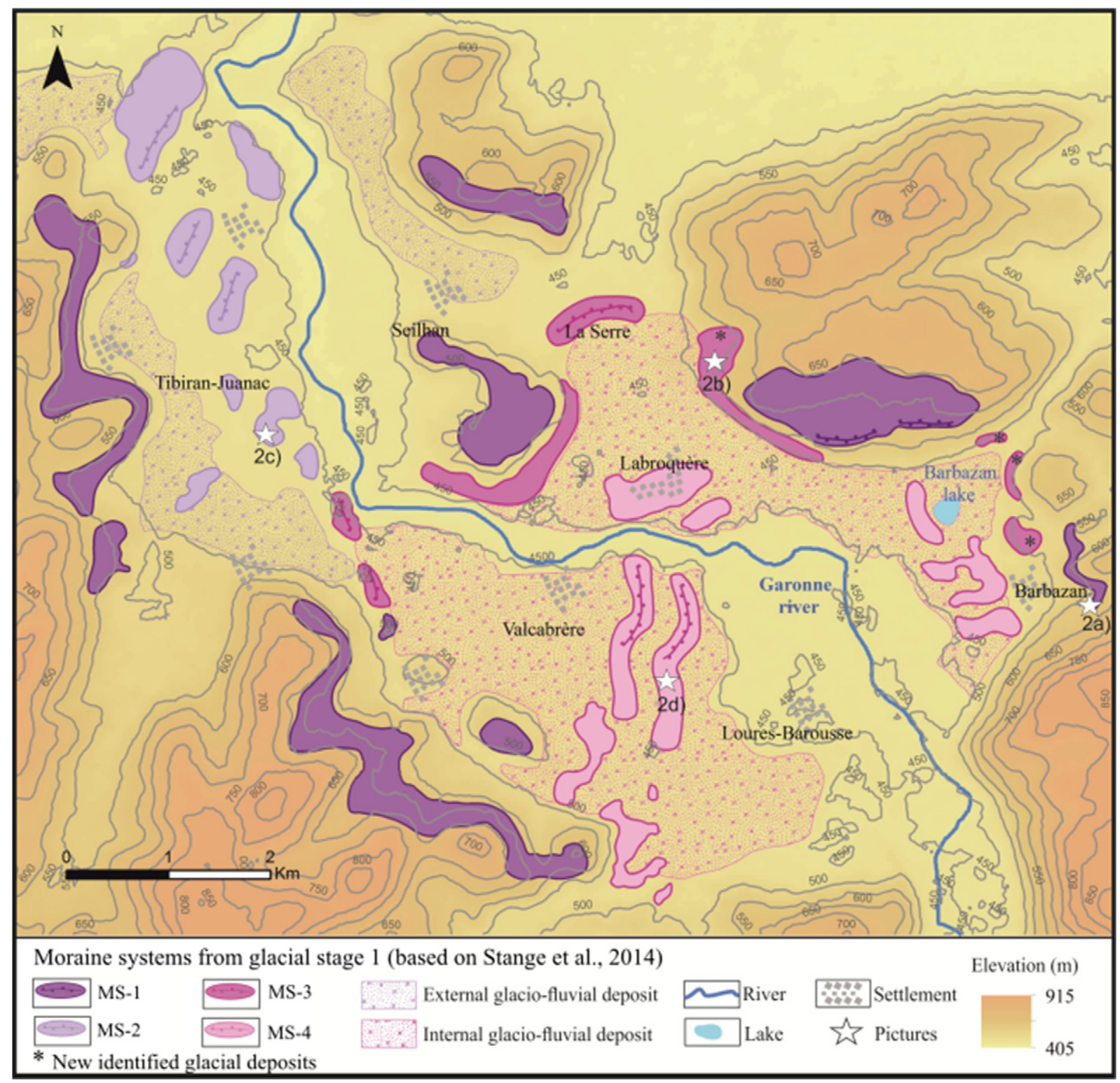

Fig. 3. Distribution of moraines formed during glacial stage 1 in the Upper Garonne basin.

origin are practically continuous on the valley floor, with the presence of moraine ridges at 950-1000 m near Vielha, $1400 \mathrm{~m}$ at the mouth of the Aiguamòg River and $1850 \mathrm{~m}$ at the exit from the Beret plateau (Fig. 5).

The best preserved moraines are distributed in the areas most distant from the ravines and alluvial fans, and therefore not affected by slope dynamics. On the right bank of the Garonne River, parallel to the built-up area between Vielha and Escunhau, there is a moraine level of greyish material perched on the slope, at ca. 100-120 m above the valley floor. It corresponds to a lateral moraine including also erratic boulders of granitic lithology on its surface. On the same stretch on the left bank there is also a moraine deposit around $1100 \mathrm{~m}$ covered with vegetation. This is a lateral moraine situated above the settlement of Escunhau. Several sedimentary outcrops show angular blocks in a sandy matrix, besides the presence of large granite blocks on its surface in a slate bedrock (Fig. 4). The line is discontinuous due to the slope dynamics associated with two streams that have eroded the moraine.

Along the valley there are other examples of glacial deposits associated with moraines, identified essentially by the break in the incline of the hillsides, and confirmed by the presence of sections with moraine material and erratic blocks (Fig. 5). At Baquèira, a large moraine deposit was identified with a width of $330 \mathrm{~m}$ and a slope angle of $14-30^{\circ}$, which crosses almost the whole village as far as the Beret plateau. There are several ca. $20 \mathrm{~m}$ high outcrops with many erratic blocks of granitic (and some calcareous) lithology on a slate bedrock (Fig. 4). All this area forms a right lateral moraine of the glacier that descended from the Ruda valley and a frontal moraine complex of the glacier that descended from Beret. This complex connects with three moraine ridges located at 1850-1900 m on the Beret plateau, which are distributed in an external position in relation to the source of the Bacivèr massif and parallel to the glacial flow that ran in this area. They are considered units of the left-side moraine of the glacial tongue that flowed towards the Noguera Pallaresa valley, and right-side deposits of the glacial tongue that flowed towards the Garonne valley. One is set in the ravine of the source of the Garonne, which ends at the settlement of Baquèira, and the other two form moraines beside the northern limit of the Beret plateau.

\subsection{Glacial stage 3}

During stage 3, the glacier abandoned the main valley of the Garonne and only developed in the highest parts of the valleys (Fig. 6). 
a)

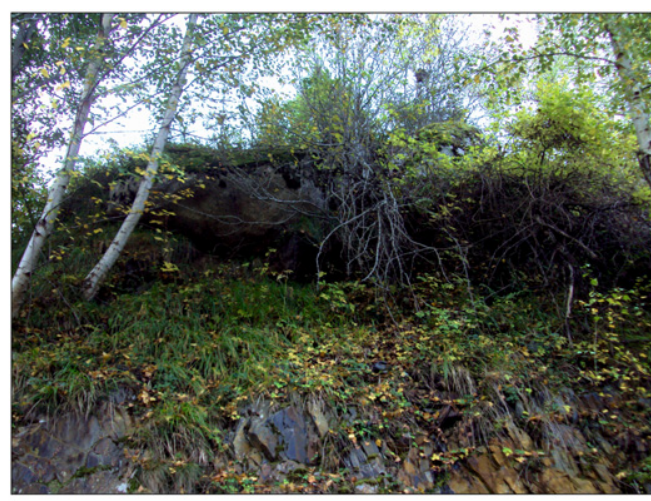

c)

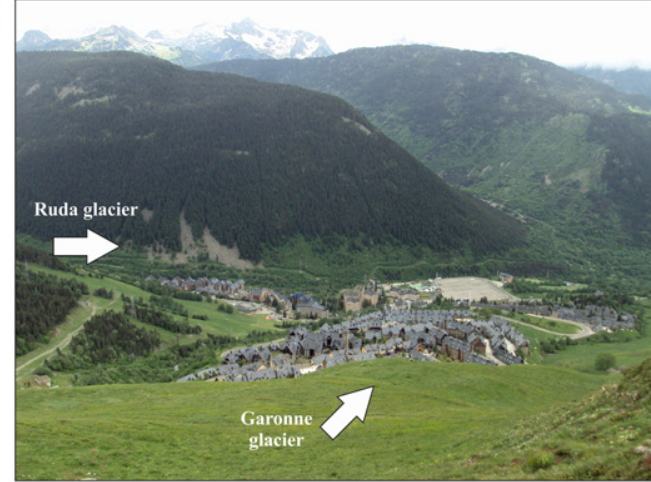

b)

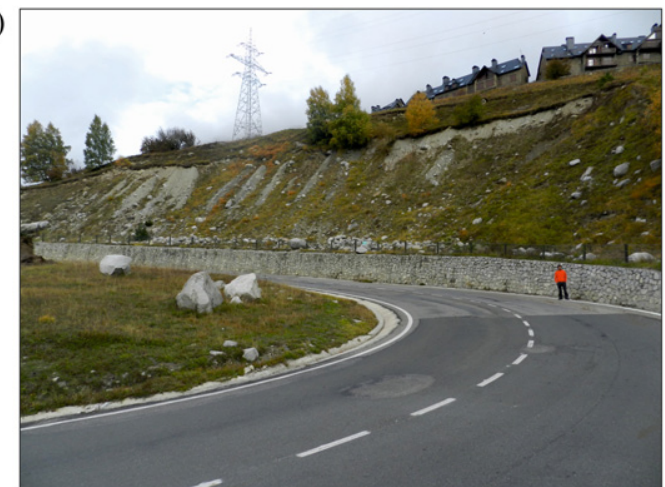

d)

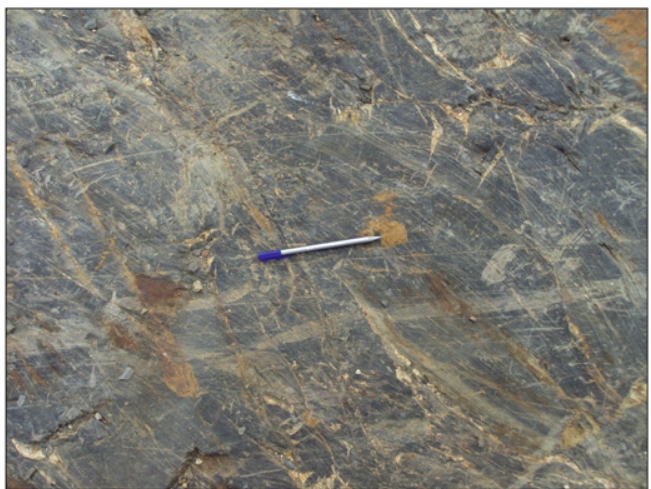

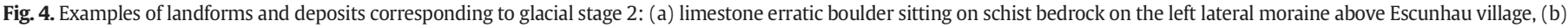

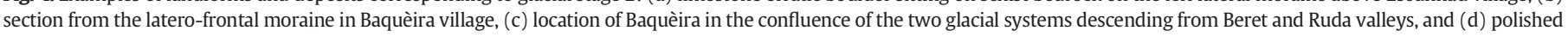
bedrock in the upper part of the Beret plateau eroded during glacial stage 2 .

In the lowest parts of the Ruda valley, morainic material is identified on the foothills of the slopes corresponding to the moraines of stage 2. In the central part of the valley, below the Saboredo cirque, there are two frontal and lateral-frontal moraines of $10 \mathrm{~m}$ in height between $2050 \mathrm{~m}$ and $2200 \mathrm{~m}$. Both are developed on the edges of overdeepened glacial basins. The first moraine system is more external and formed of three frontal ridges transversal to the flow. In the highest and innermost part, the lateral-frontal moraines are smaller and divided by an overdeepened basin.

The Beret plateau shows a succession of moraine crests besides being covered with widespread till and angular erratic blocks of granite of 1-5 m scattered on the surface. This succession of episodes of moraine deposition is associated with stage 3 . In a more internal position compared to stage 2, there are two moraine complexes distributed in the bed of the ravine of the Malo stream, near Baquèira (Fig. 7). The local relief structure gives them an elongated form parallel to the glacial flow forming lateral-frontal moraines. In the central part of the plateau, the topography and greener vegetation denote another moraine system with an elongated form perpendicular to the flow of the glacier that descended from the Bacivèr valley.

\subsection{Glacial stage 4}

The moraine bodies associated with this stage are always of frontal or lateral units inside the cirques, where the conditions for

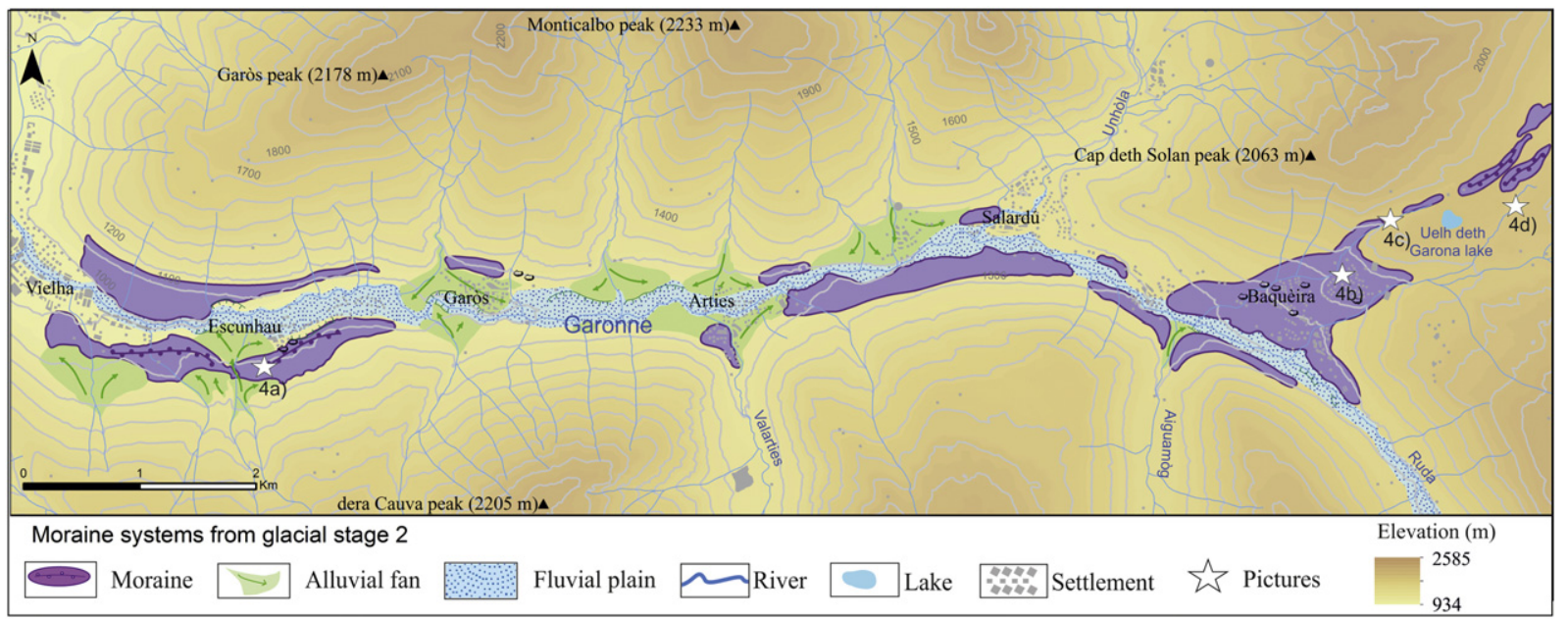

Fig. 5. Distribution of moraines formed during glacial stage 2 in the Upper Garonne basin, namely in Val d'Aran district. 
a)

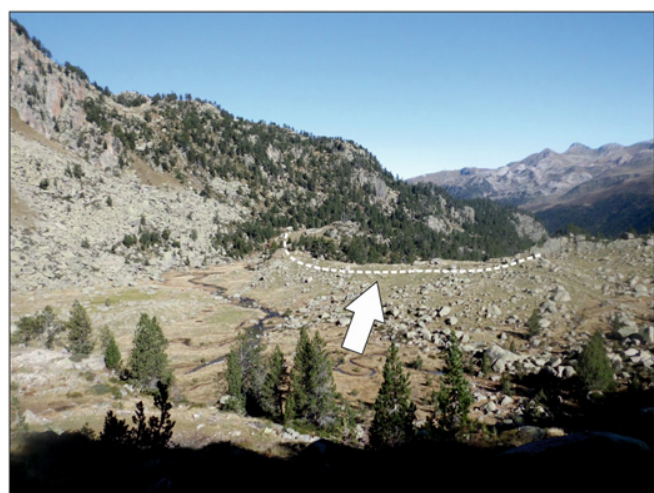

c)

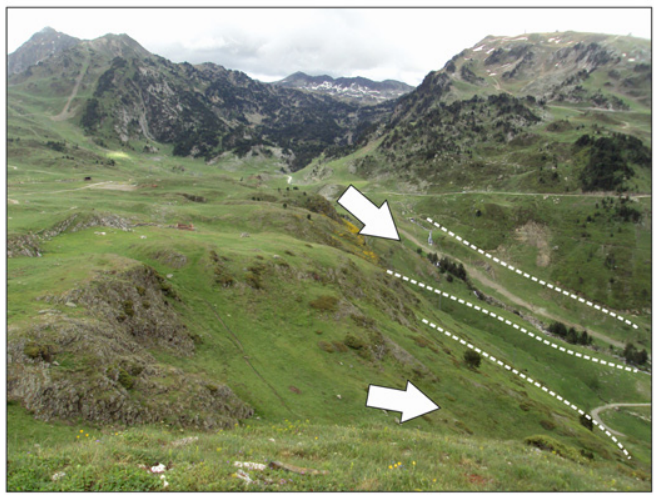

b)

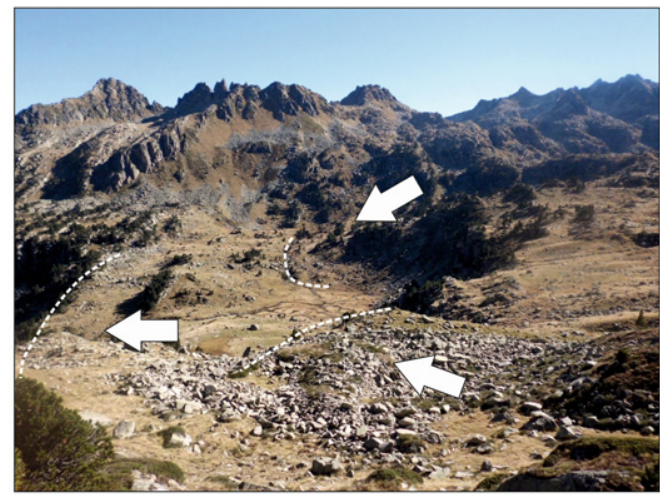

d)

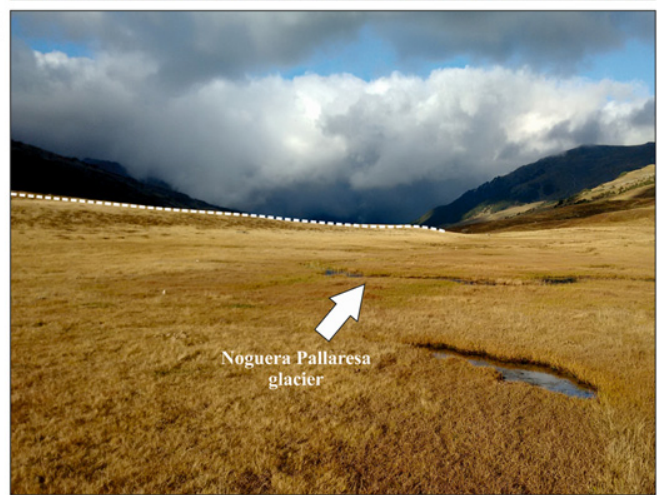

Fig. 6. Moraines generated during glacial stage 3: (a) external frontal moraine in Ruda valley, (b) internal moraines in Ruda valley, (c) moraine ridges descending from Bacivèr massif in the exit of Beret plateau, and (d) moraine ridge in Beret plateau towards the Noguera Pallaresa valley.

accumulation and preservation of the glacial ice were more favorable in the last stage of deglaciation. They are both on the bottom and on the threshold of the highest glacial cirques at heights above $2300 \mathrm{~m}$. On the threshold of the Sendrosa cirque there are various lateral ridges reaching $400 \mathrm{~m}$ in length; on the threshold of the Locampo cirque, the moraine presents a frontal crest, and on the threshold of the Saboredo cirque there is a frontal moraine between the lakes of Major de Saboredo and Naut de Saboredo. The moraines at the bottom of the glacial cirques are found at the base of the cirques around $2600 \mathrm{~m}$ and present a fresh state of conservation. They are always small frontal moraines of $10-20 \mathrm{~m}$ in height, and some show evidence of post-glacial flow forming incipient rock glaciers (Fig. 8b). In the Beret area several small

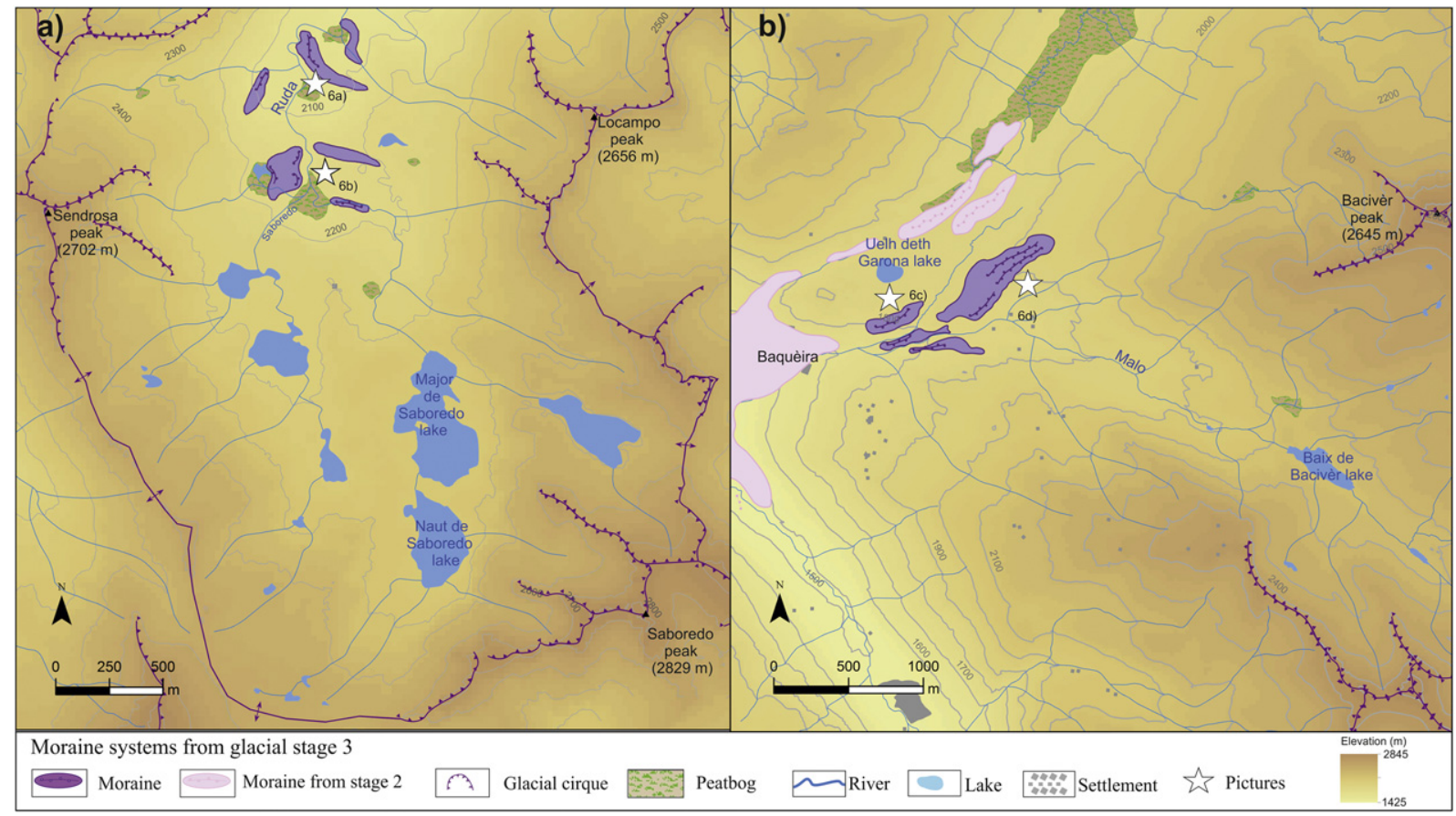

Fig. 7. Distribution of moraines formed during glacial stage 3 in Ruda and Beret areas. 
a)

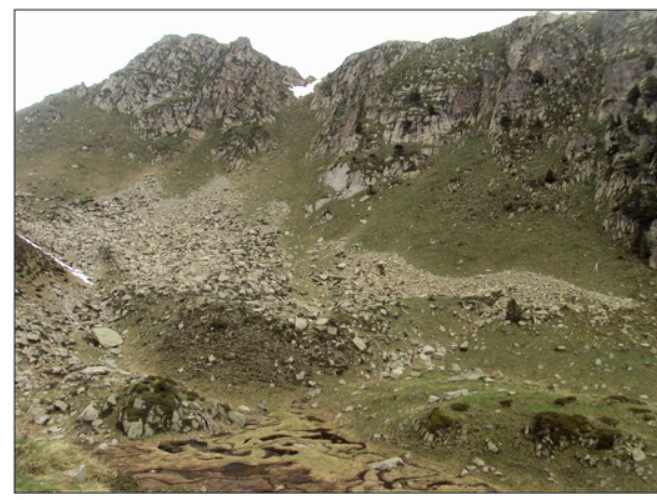

c)

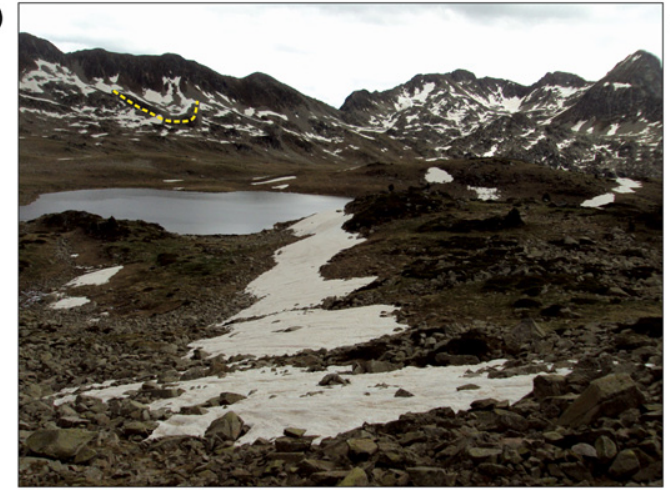

b)

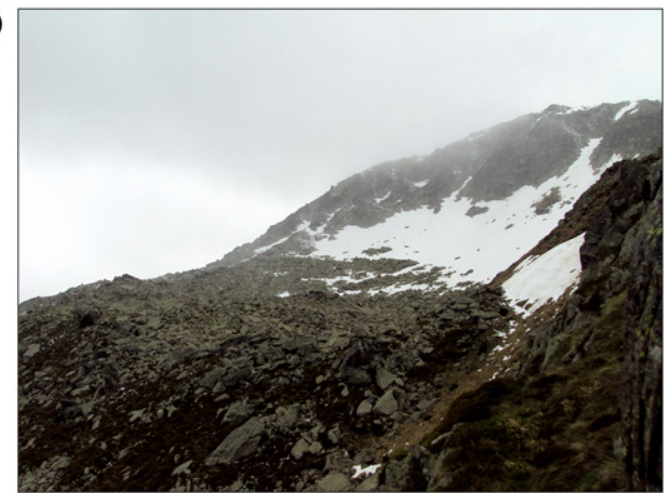

d)

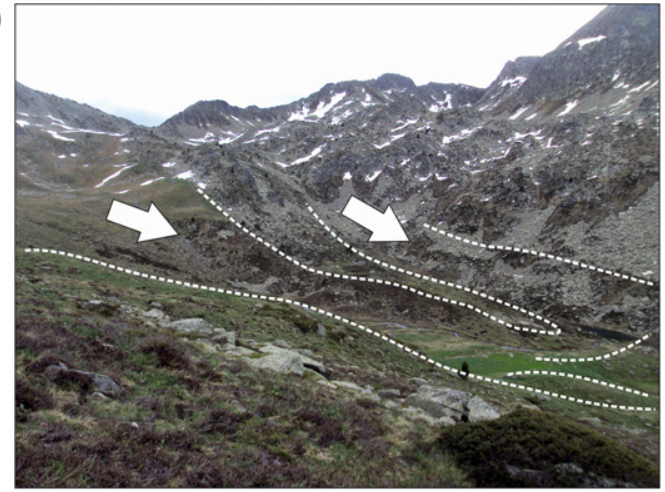

Fig. 8. Moraines from glacial stage 4: (a, b) cirque moraines in the northern side of the Sendrosa peak, and (c, d) within the Bacivèr massif.

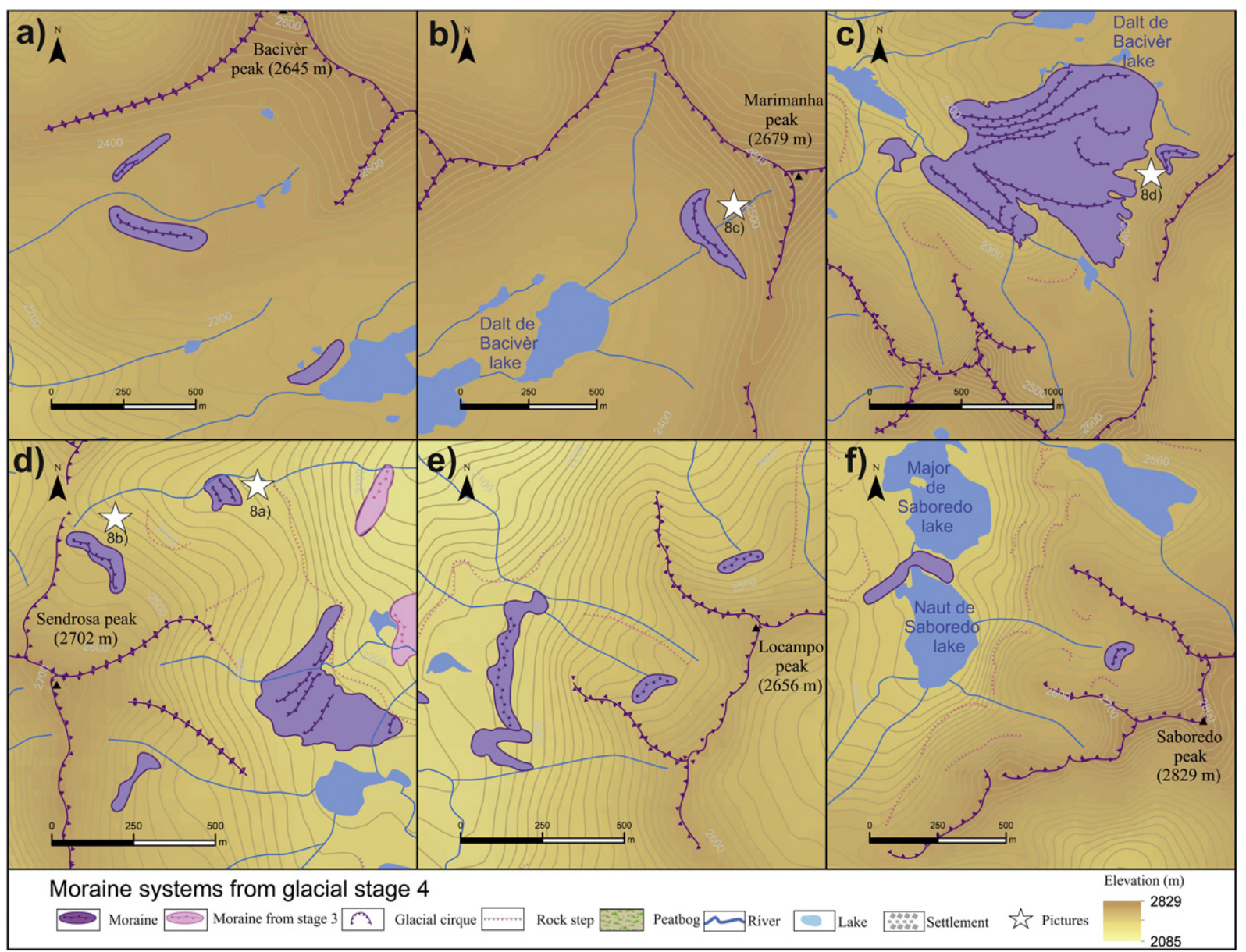

Fig. 9. Distribution of moraines formed during glacial stage 4 in Ruda valley e Beret areas. 
alpine glaciers developed during glacial stage 4 that subsequently formed cirque glaciers at the foot of the headwalls. The alpine glaciers generated lateral moraines 550-790 m long, while the uppermost moraines show smaller lengths (120-240 m). In both cases the moraine ridges present a low height (5-20 m) (Fig. 9).

\subsection{Reconstruction of paleoELAs and paleo-glaciers}

Calculation of ELAs according to Pellitero et al. (2015) suggests that during stage 1 the altitude where the accumulation and ablation were balanced was at $1532 \mathrm{~m}$. Subsequently, within the deglaciation process, the stabilization of the glaciers in the valleys in stage 2 suggests an ELA of $1982 \mathrm{~m}$. Stage 3 is characterized by a glacial retreat that individualizes the glaciers in the valleys, with an ELA at $2336 \mathrm{~m}$. Finally, in the last glacial stage with construction of cirque moraines the ELA was at an altitude of $2408 \mathrm{~m}$ (Table 1 ).

Regarding the extent of the glaciers based on the location of the outermost moraine systems of each stage, the surface and volume occupied by the ice in the upper Garonne basin during the different glacial stages was modeled with the GLARE tool (Pellitero et al., 2016) (Fig. 10).

\subsubsection{Stage 1}

The upper Garonne was well filled with ice during the MIE stage (Fig. 10). The glacial system, from Tuc de Saboredo to the outermost moraine unit of the Loures-Barousse-Barbazan basin, was $87.8 \mathrm{~km}$ long. The thickness of the glacier reached ca. $835 \mathrm{~m}$ in the center of the main valleys, with a surface of ca. $960 \mathrm{~km}^{2}$ (ca. $76.2 \%$ of the basin) and a total ice volume of ca. $260 \mathrm{~km}^{3}$, resulting from the confluence of two major ice tongues, the one coming from the Val d'Aran with the one descending from La Pique (Fig. 10). Glaciers were mainly alpine-type until the Loures-Barousse-Barbazan basin, where the ice spread out forming a piedmont glacier. The mountain tops, mainly the highest ones, were ice-free and functioned as nunataks. In the areas where the ice thickness reached the mountain tops there was glacial transfluence: at the saddle of Bossòst, Port de la Bonaigua or at the heads of Vadarròs with Unhòla (Fig. 10). There are also examples where the glacier system showed diffluence, as already mentioned in the case of the Beret plateau. It is possible that the model contained some errors, namely at the heads which should have been more covered with ice in this stage.

\subsubsection{Stage 2}

The lack of conservation of the frontal moraine of stage 2 in this sector makes it difficult to define the limit of the glacier, which was drawn

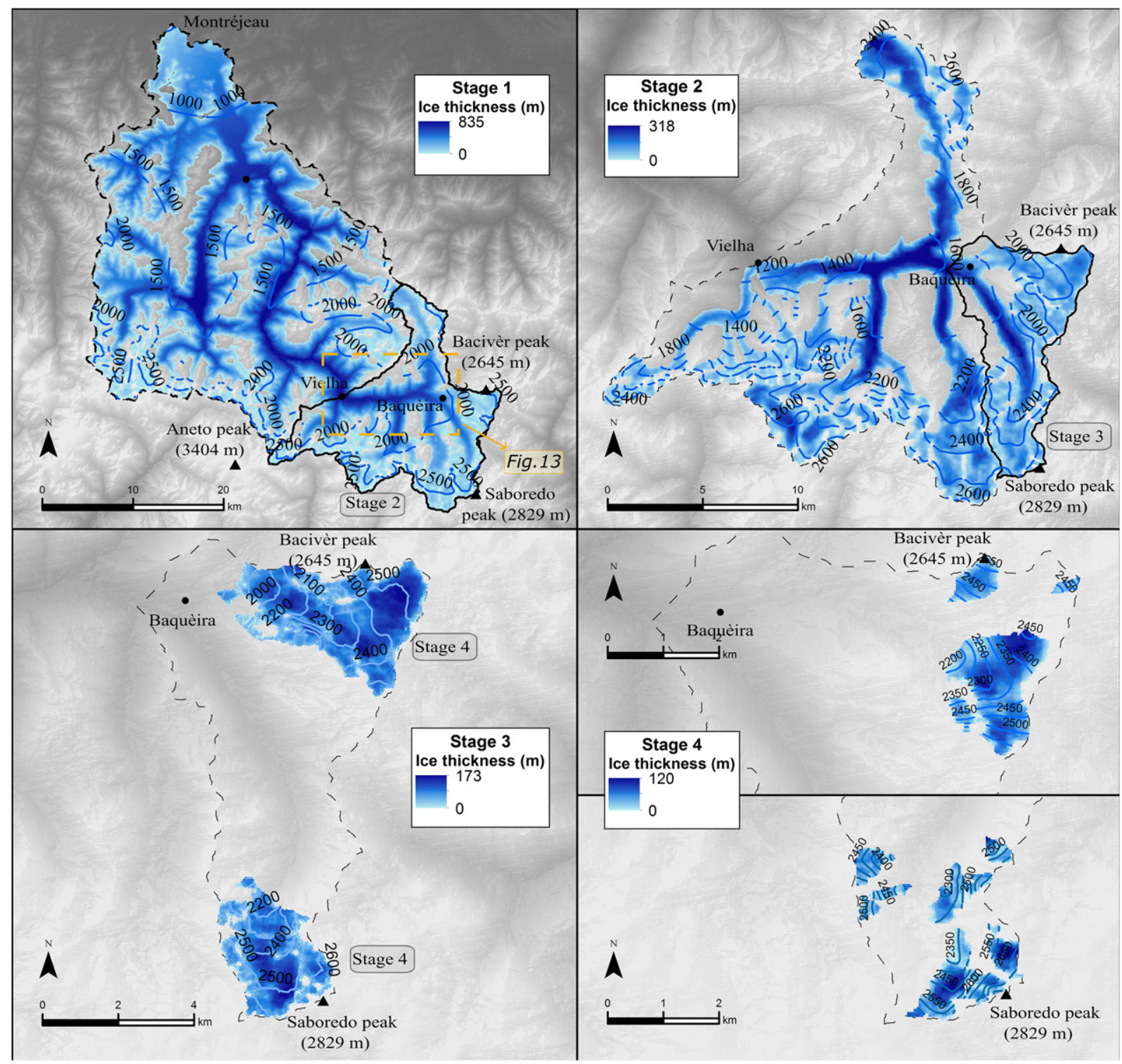

Fig. 10. Reconstruction of paleo-glaciers for each of the glacial stages. 
up from the extent of the lateral moraines downstream. The width of the glacier in this sector, $600 \mathrm{~m}$ according to the difference between the thresholds of the moraines at Escunhau, was added in the model's calculations (Fig. 10).

The valley floor of the Vielha-Escunhau section was filled with ice during the second stage. The glacial tongue from Tuc de Saboredo to the outermost moraine of Vielha was $23 \mathrm{~km}$ long, coming from the heads with significantly less thickness and volume than in stage 1 . In the main valleys the thickness reached ca. $318 \mathrm{~m}$, with a glacierized surface of ca. $157 \mathrm{~km}^{2}$ and an ice volume of ca. $14 \mathrm{~km}^{3}$. The glaciers were exclusively alpine, with nunataks in the highest ice-free parts of the mountains. The glacier suggests areas with glacial diffluence (e.g. Beret), transfluence (e.g. Coll de Sendrosa) and confluence of the tributaries of Unhòla, Valarties, Aiguamòg and Ruda, and it seems the remaining ones were already isolated in their valleys. Interestingly enough, during stage 2 the Baquèira area was still covered with ice, but the western half of Beret no longer was, which explains the moraine complex deposited on the outside edge of Beret. The model seems to present errors in the high parts of Unhòla and Valarties valleys, which begin to have glacial ice halfway down the valley.

\subsubsection{Stage 3}

The glacial modeling for stage 3 considers the outermost moraine systems of Ruda and Beret areas. The maximum width of the glacier during this stage was ca. $200 \mathrm{~m}$ according to the elevation difference between the Ruda lateral moraine ridges.

Only the high parts of the upper Garonne were filled with ice during stage 3, namely the plateaus, glacial cirques and the highest parts of the valley floors. The Beret and Ruda glaciers became disconnected. The glacier length in the Ruda valley, from Tuc de Saboredo to the outermost moraine, was only $2.6 \mathrm{~km}$. In Beret, the plateau was no longer covered with ice and the glacier remained at the mouth of the Bacivèr valley, where there is the moraine system left by the $4.5 \mathrm{~km}$ long ice tongue that descended from the Bacivèr massif. The thicknesses of the ice were less significant, with the maximums accumulated at the bottom of the overdeepened glacial basins of ca. $179 \mathrm{~m}$ in the Bacivèr massif and ca. $160 \mathrm{~m}$ in that of Saboredo. The total ice volume of this stage was ca. $1 \mathrm{~km}^{3}$, with ca. $0.6 \mathrm{~km}^{3}$ on Beret and ca. $0.4 \mathrm{~km}^{3}$ in Ruda, together covering ca. $16 \mathrm{~km}^{2}$ of surface. They were both valley and cirque glaciers in the lowest areas (Fig. 10).

\subsubsection{Stage 4}

Paleo-glacier modeling of the high parts of the upper Garonne during stage 4 considered various glacial units. The limit of each glacier was defined by the outermost frontal moraine located in the highest cirques. During stage 4, glaciers abandoned the bottom of the Ruda valley and originated various cirque glaciers isolated at the heads, or incipient valley glaciers that reached the thresholds of the cirques with between $400 \mathrm{~m}$ and little $>2 \mathrm{~km}$ in length. The greatest thicknesses were found at the bottom of the glacial cirques, reaching ca. $120 \mathrm{~m}$ in the Saboredo cirque. The glaciers covered a surface of ca. $5.7 \mathrm{~km}^{2}$ and encompassed a total volume of ca. $0.19 \mathrm{~km}^{3}$, with ca. $0.1 \mathrm{~km}^{3}$ in Beret and ca. $0.09 \mathrm{~km}^{3}$ in Ruda.

\section{Post-glacial geomorphological processes in the upper Garonne valley}

A wide range of glacial, periglacial, slope, nival and alluvial features formed during different environmental stages are found in the Ruda valley and Beret plateau (Fig. 11). The mapping of the distribution of landforms and processes in these areas provides evidence of the post-glacial environmental evolution in the highest parts of the basin.

\subsection{Ruda valley}

The fluvial floodplain is situated in the long valley bottom between $1400 \mathrm{~m}$ and $1900 \mathrm{~m}$. It is a narrow sedimentary unit conditioned by the U-shaped form of the valley. Today, the accumulation of sediments transported by the fluvial dynamics occurs in the relatively flat areas on the valley floor, where the topography favors depositing. Currently, fluvial processes are characterized by the nivo-pluvial fluvial regime, which conditions greater geomorphic activity during the spring thaw. Remnants of the moraine left by the glacier in stage 2 are retained near the foot of the slopes, which were later washed and eroded by post-glacial dynamics (namely fluvial and slope processes). Erratic boulders are distributed across the most distant surface of the alluvial fans. Valley slopes are covered by deposits resulting not only from current activity but also from past processes associated with paraglacial and periglacial dynamics. Immediately after the glaciers' retreat, the rocky slopes were subject to instability due to the glacial loosening (paraglacial stage) and mechanical weathering (periglacial processes). Consequently, the material affected by these processes was freed, precipitated and covered the hillsides, forming debris slopes. Subsequently and until today, these slopes have been affected by seasonal dynamics triggered by liquid water (alluvial dynamics) and snow (nival dynamics), depending on the altitude and the time of year. The hillsides in these areas often show a scar in the highest part of the slopes; a steep and narrow sliding surface which coincides with the heads of the ravines where seasonal streams run; the fan that shows abundant superficial grooves left by the debris flows; and a lower slope that gradually ends in the valley bottom of the Ruda River. As height is gained, particularly above $1800 \mathrm{~m}$, a change in slope features is perceptible. Alluvial fans are found with evidence of mixed dynamics, created by debris flows associated with the presence of water in liquid state preferably during the thaw season, and by snow avalanches during the cold season. The degree of vegetation development and its density is indicative of the areas most frequently affected by avalanches.

From the morphology of the slopes of the Ruda valley it is possible to identify a glacial shoulder ca. $400 \mathrm{~m}$ above the valley floor. This glacial erosion landform is characterized by a rocky edge $\left(30-50^{\circ}\right)$, which marks the limit of the glacier during stage 1 , as suggested by the model (Fig. 10). Numerous remains of past glacial and periglacial activity can be found with a wide range of erosion and accumulation landforms. Above $2000 \mathrm{~m}$, there are many basins shaped by glacial overdeepening today covered with sediment and wetlands or by small seasonal or permanent lakes. Post-glacial environmental dynamics favored these depressions being filled with sediment (often functioning as proglacial lakes), namely during the paraglacial stage. At their edges, there are polished surfaces and rocky walls (upstream) with moraine (downstream). Traces of glacial abrasion caused by the ice flow can be seen on the polished surfaces, such as roche moutonnée and striae of millimetric and centimetric size. The glacial basins are closed by numerous well-preserved frontal moraines corresponding to stage 3 . The surrounding slopes include abundant debris cones, showing moderate slopes $\left(10-40^{\circ}\right)$ and essentially oriented to the west. These are active landforms at present associated with gravitational processes enhanced by freeze-thaw action.

Glacial cirques - landforms resulting from glacial and periglacial erosion (Barr and Spagnolo, 2015) - are distributed above $2200 \mathrm{~m}$. In the Ruda valley they show vertical differences of up to 300-600 m between the bottom and the top. Inside the glacial cirques there are many landforms of glacial and periglacial origin, some of which are currently active while others have been inherited from past stages. Therefore, and corresponding to stage 4 of the glacial sequence, there are different freshly preserved moraine complexes. Rock glaciers, protalus lobes and solifluction landforms can be found within the glacial cirques between 2210 and $2580 \mathrm{~m}$. Several protalus ramparts are distributed near the vertical walls of the highest cirques. In general, cryogenic 


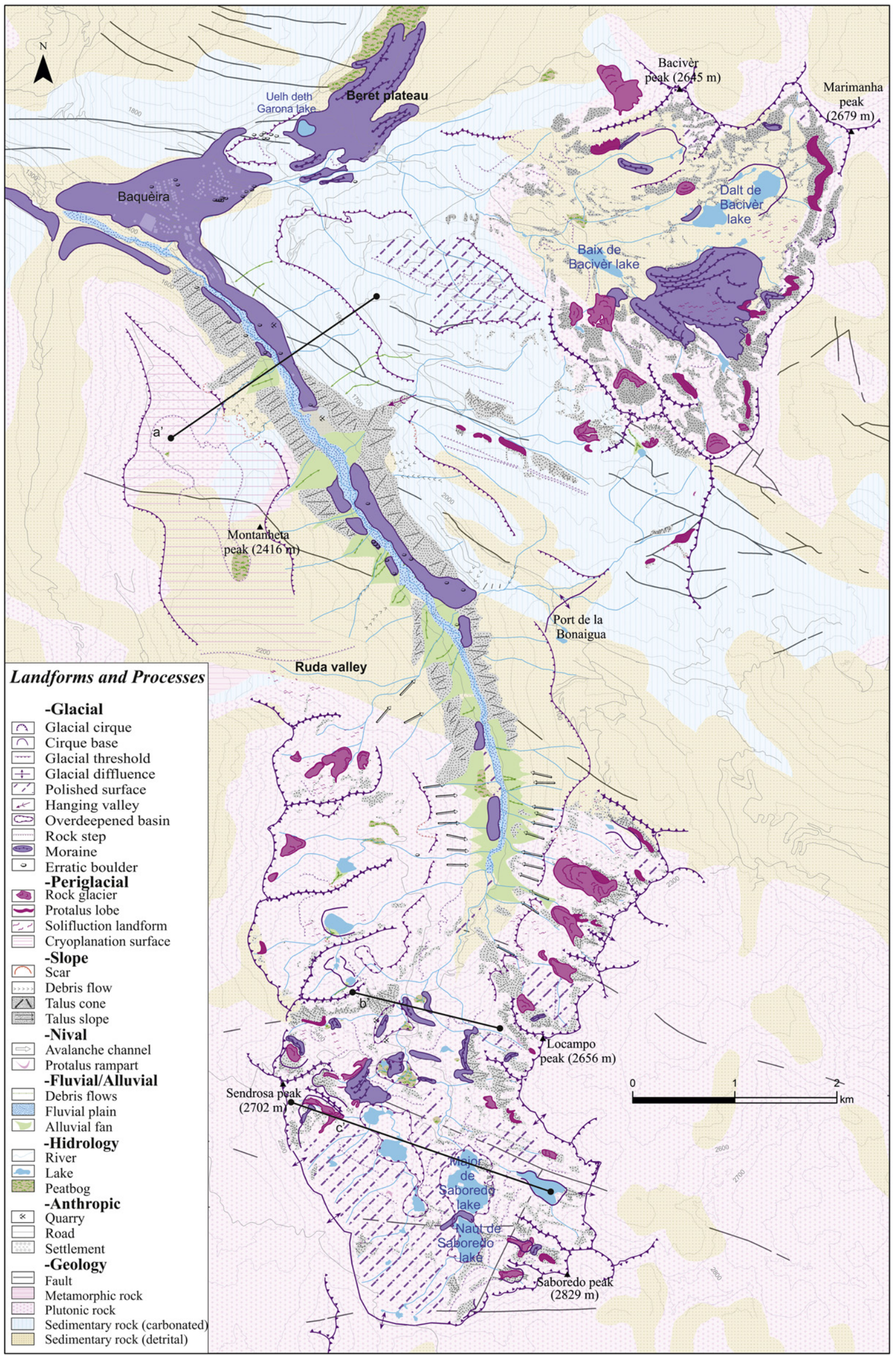

Fig. 11. Geomorphological map of the upper Garonne valley, namely Beret plateau and Ruda valleys. 
processes are active above $2300 \mathrm{~m}$, and micromorphologies associated with daily freeze-thaw cycles in the soil are abundant, such as those generated by pipkrake. Finally, in the highest parts of the study area, at the level of the crests of the glacial cirques (2600-2800 m), there are gentle surfaces that were affected by glacial transfluence, as well as rocky ridges that functioned as nunataks. On the left bank of the Ruda River, at the confluence with the Garonne River, there are cryoplanation surfaces already described by Kleinsmiede (1960) and Martí-Soler (1988).

\subsection{Beret area}

In the flat area of Beret plateau a well-developed moraine complex composed of ten moraine ridges was deposited at elevations between 1860 and $1915 \mathrm{~m}$ (Fig. 11). Between 1870 and 2100 m, a U-shaped valley including a glacial trough can be observed, with the presence also of several roches mountonnées and polished surfaces. This glacial trough has a small tributary glacial valley coming from the area of the Tuc de Bacivèr peak. Glacial retreat in the narrow trough generated several rock avalanches during the paraglacial stage. The slopes of the main valley are partially covered by talus slopes with varying degrees of activity. Some of these talus slopes are fed also by snow avalanche channels.

Above $2100 \mathrm{~m}$ the narrow valley widens and forms a high altitude plateau where an extensive moraine system east of Baix of Bacivèr Lake is preserved. In addition, there are other two lakes and numerous lagoons in overdeepened basins shaped by glacial erosion. The morainic complex is composed of seven lateral moraines and four moraine arches. Solifluction processes are currently active on the unconsolidated moraine sediments. Glacial diffluence occurred next to the NE fringe of the moraine complex.

This plateau located in the upper part of the glacial valley encompasses several glacial cirques forming a wide amphitheatre. The bottom of the cirques is placed at altitudes between 2270 and $2430 \mathrm{~m}$, whereas the peaks range between 2437 and $2679 \mathrm{~m}$. Glacial cirques show height differences of up to $130-350 \mathrm{~m}$ from the bottom to the top. Inside the glacial cirques there are numerous glacial and periglacial landforms. As occurs in the highest parts of Ruda valley, some of these landforms are active or weakly active. Conversely, many other landforms are inherited from previous morphoclimatic conditions. At the foot of one of the cirque walls at the eastern part of the plateau, a frontal fresh and well-preserved moraine ridge is distributed, suggesting the last glacial stage before the complete deglaciation of the area (Fig. 11). Another moraine complex composed of two lateral moraines is located in the southern face of the Tuc de Bacivèr peak. Rock glaciers and protalus lobes are located at the lowest parts of the cirque walls and at the foot of the rocky ridges between 2267 and $2480 \mathrm{~m}$. They are currently inactive landforms since no permafrost regime conditions are found in the area. Protalus ramparts are abundant and still active and semiactive. Some landforms present transitional morphologies between protalus ramparts and protalus lobes. Also, in the sector of the Tuc deth Rosari (2607 m), transitional landforms between a glacial moraine and protalus lobes/ramparts are observed, suggesting glacionival dynamics during the last phase of the glacial stage 4. Snow avalanche channels, generated on granite and metamorphic rocks, are very abundant in the walls of the glacial cirques. Solifluction landforms such as lobes and terracettes are very abundant on slopes covered by fine particles. Today, nival processes and cryonival dynamics related to freeze-thaw cycles (frost shattering, cryoturbation, etc.) are very active.

\section{Discussion}

A detailed mapping of the landforms and deposits left by glacial processes during the Last Glaciation allows the reconstruction of the maximum glacial extent as well as inferring the succession of glacial stages in the upper Garonne basin during the deglaciation process. Moreover, accurate geomorphological mapping in the highest lands of this basin, namely in the Ruda valley and Beret plateau, allows a better understanding of the postglacial environmental evolution and the presentday distribution of geomorphic processes in the highest lands.

\subsection{Glacial evolution in the upper Garonne basin in the context of southern European mountains}

The upper Garonne basin shows four moraine complexes associated with specific stages (Fig. 12). A similar succession of glacier stages was already observed by Delmas et al. (2011) in the basins of the Ariège, Gave de Pau, Gave de Ossau and Gállego rivers.

Glacial stage 1 generated a terminal moraine complex in the LouresBarousse-Barbazan basin at elevations of $460-640 \mathrm{~m}$ at the northern foothill of the Central Pyrenees (Table 1). Covering a distance of $87.8 \mathrm{~km}$ it was one of the longest glaciers in the Pyrenees. Therefore, this stage is associated with the moraine complex corresponding to the maximum glacial advance, where the ice tongues filled the valleys from the highest parts of the upper Garonne basin ending in a piedmont glacier in the Loures-Barousse-Barbazan basin.

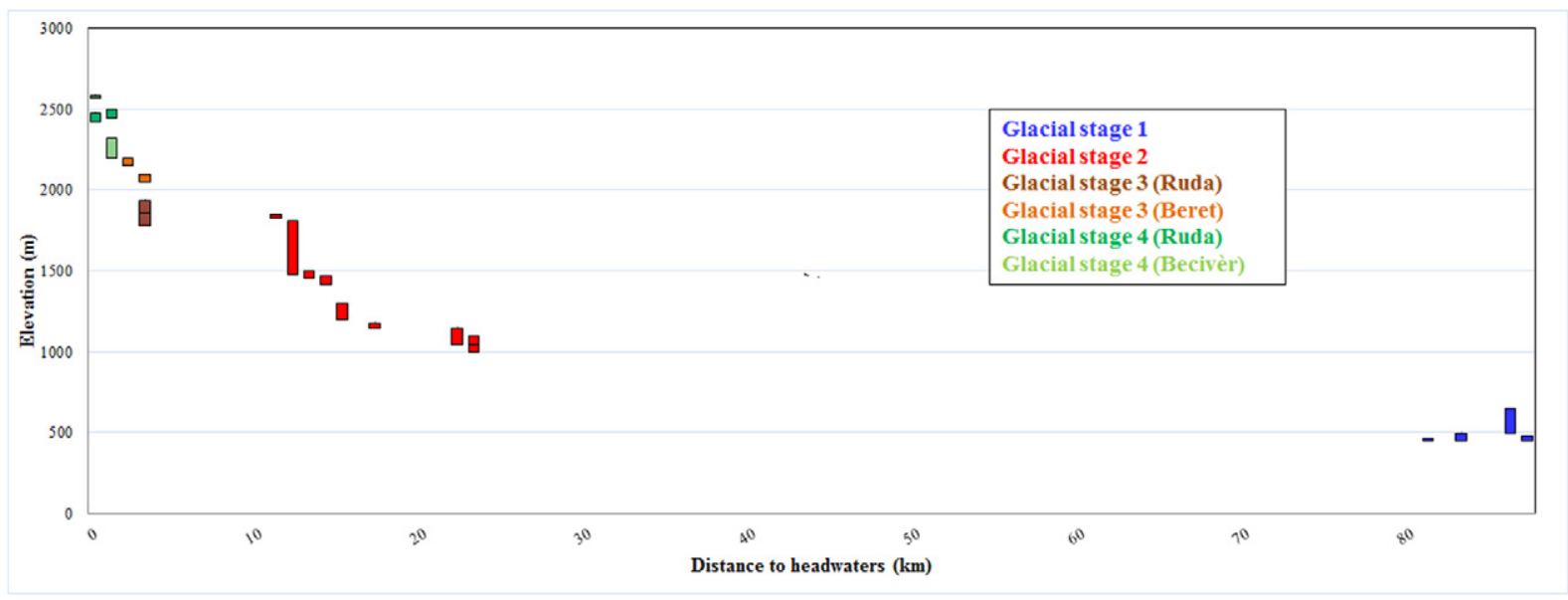

Fig. 12. Elevation distribution of the identified glacial deposits corresponding to the different glacial stages and their distance from the headwaters. 
Table 1

Main characteristics of glaciation for each stage.

\begin{tabular}{|c|c|c|c|c|c|c|c|c|}
\hline Glacial Stage & Glacial type & $\begin{array}{l}\text { Elevation moraines } \\
(\mathrm{m})\end{array}$ & $\begin{array}{l}\text { Distance from head } \\
(\mathrm{km})\end{array}$ & $\begin{array}{l}\text { Max. ice thickness } \\
(\mathrm{m})\end{array}$ & $\begin{array}{l}\text { Glaciated surface } \\
\left(\mathrm{km}^{2}\right)\end{array}$ & $\begin{array}{l}\text { Ice volume } \\
\left(\mathrm{km}^{3}\right)\end{array}$ & $\begin{array}{l}\text { ELA } \\
(\mathrm{m})\end{array}$ & Possible chronology \\
\hline Stage 1 & Alpine/piedmont & $460-480$ & 88 & 835 & 960 & 260 & 1532 & MIS 4-MIS 2 \\
\hline Stage 2 & Alpine & $1000-1850$ & $23-12$ & 318 & 157 & 14 & 1982 & Older Dryas \\
\hline Stage 3 & Alpine/cirque & $2050-2200$ & $4.5-2.6$ & 179 & 16 & 1 & $2336^{a}$ & Younger Dryas \\
\hline Stage 4 & Cirque/alpine & $2260-2590$ & $2-0.4$ & 120 & 5.7 & 0.19 & $2408^{\mathrm{b}}$ & Holocene \\
\hline
\end{tabular}

a Mean values. ELAs were at 2411 and $2253 \mathrm{~m}$ for Ruda and Beret valleys, respectively.

b Mean values. ELAs were at 2435 and $2381 \mathrm{~m}$ for Ruda and Beret valleys, respectively.

The ELA was located at $1532 \mathrm{~m}$, which suggests a depression of $1184 \mathrm{~m}$ with respect to present-day $0{ }^{\circ} \mathrm{C}$ isotherm. Based on the assumption that glacier mass balance was controlled solely by ablationseason temperature (Porter, 2000), and assuming past temperature lapse rate in the Central Pyrenees similar to present-day, the depression of mean annual temperatures during the local maximum glacial extent during the Last Glaciation was ca $7.1{ }^{\circ} \mathrm{C}$. Therefore, projected paleotemperatures at the highest altitudes of the study area $(2800 \mathrm{~m})$ during local maximum glacial extent during the Last Glaciation would result in ca. $-8{ }^{\circ} \mathrm{C}$. These values are similar to those calculated in other studies considering different scenarios of precipitation anomalies during the LGM (Allen et al., 2008).
The model agrees with the presence of glacial thresholds indicating the area affected by glacial erosion, which means that the ice thickness reached $400-600 \mathrm{~m}$ in the Nere and Joeu valleys and $800 \mathrm{~m}$ in the Garonne glacier between Vielha and Marignac (Fig. 13). This stage shaped glacial valleys, overdeepened basins, glacial cirques, cryoplanation surfaces and ice-free areas between neighboring valleys, with their tops functioning as nunataks (Bordonau, 1985, 1992; Martí-Soler, 1988). Stage 1 left the terminal glacial records in the Loures-BarousseBarbazan basin forming 4 moraine systems. The MS-1, located on the slopes surrounding the basin, was thought to pre-date the Last Glaciation, possibly from MIS 6 (Hubschman, 1984; Andrieu, 1991); it correlates with fluvial deposits in the same area at a higher altitude (Stange
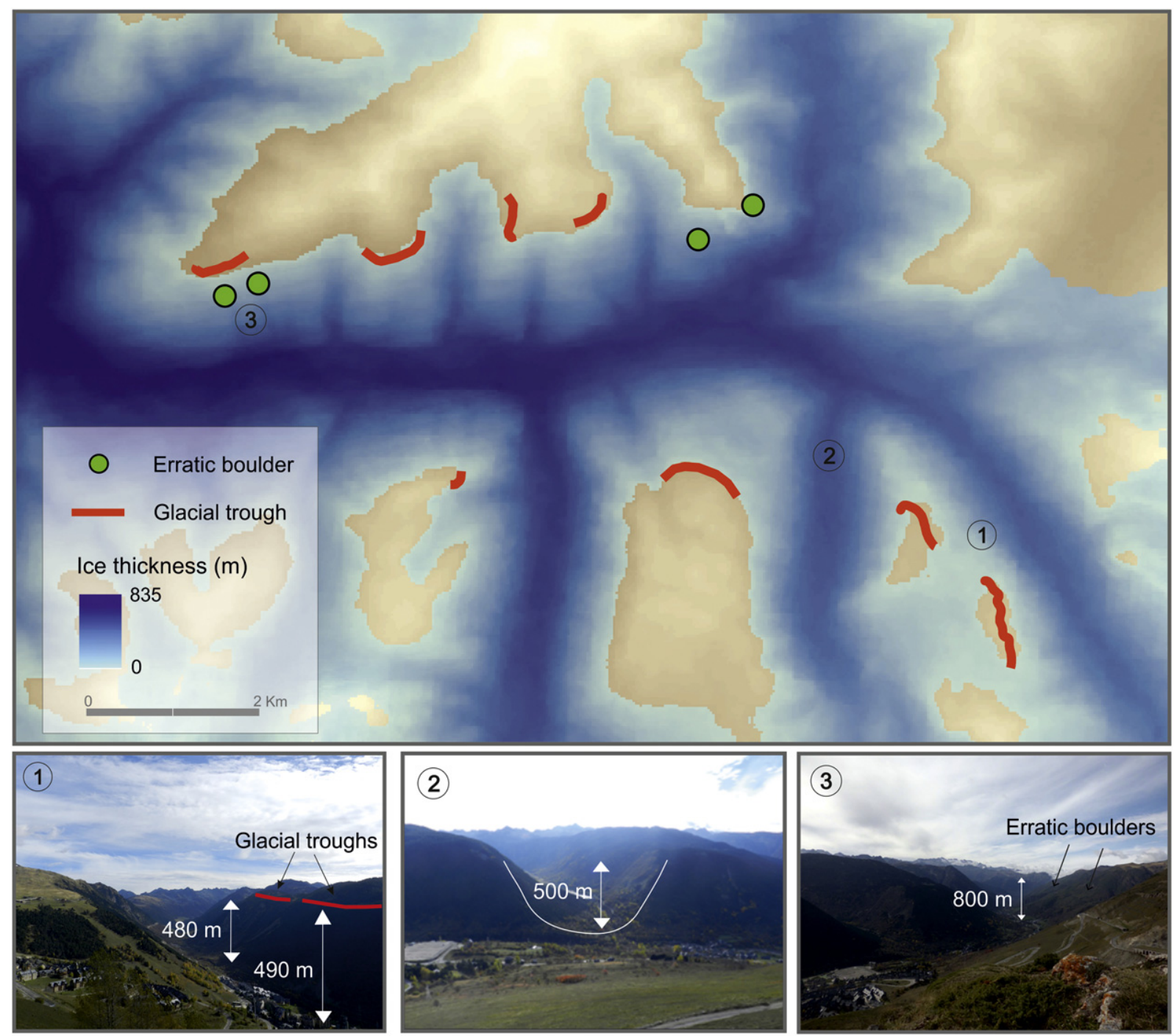

Fig. 13. Distribution of glacial troughs and erratic boulders corresponding to stage 1, together with the ice thickness generated by the model for the upper Garonne valley. 
et al., 2014). Other valleys in the Pyrenees also contain moraine deposits from before the Last Glaciation with similar degradation characteristics at a short distance from deposits from the MIE ( $6 \mathrm{~km}$ in the Ariege valley; Delmas et al., 2011; 2 km in the Gállego valley; Peña et al., 2004), as also occurs with fluvio-glacial sediments (Têt valley; Delmas et al., 2008; Delmas, 2009).

MS-2 seems to correspond to the maximum advance of the Last Glaciation in the upper Garonne basin. From pollen in the nearby Sòst lake, Herail and Jalut (1986), a glacial maximum of $\sim 45$ ka was inferred, but this age may be contaminated by the hard water effect (Pallàs et al., 2006). Stange et al. (2014) also suggested that the basal ${ }^{14} \mathrm{C}$ dates of the glaciolacustrine sequence of Barbazan could be older than the 32$39.4 \mathrm{ka}$ cal BP proposed by Andrieu (1991), referring to the fact that the glacial conditions prevailing in the area must have limited the development of soil organic carbon. The attribution of a MIE preceding the LGM for MS-2 has been considered based on the morphology and degree of degradation of the moraines, taking into account the long exposure period between MS-2 and MS-3/MS-4 (Hubschman, 1984; Stange et al., 2014). The moraine systems of this stage were also found in other northern valleys of the Pyrenees, and were dated at 39.547.9 ka cal BP in Gave de Pau (Mardones and Jalut, 1983; Reimer et al., 2013) and at 34.9-81 ka in Ariège (Delmas et al., 2011). This chronology coincides with that of some valleys in the southern slopes of the Pyrenees (e.g. Gállego; Peña et al., 2004) and also with those of the Cantabrian Mountains (e.g. Picos de Europa at 35-45 ka cal BP, Nieuwendam et al., 2015; Ruiz-Fernández et al., 2016a). The moraine system at the foot of the slopes and the frontal complex of La Serre (SM-3) have been associated with the LGM. From their lesser degree of degradation, Stange et al. (2014) proposed a somewhat younger age for the MS-3/MS- 4 systems in relation to MS-2 and suggested that the MS-3 moraine formation coincided with the maximum glacial development of MIS-2, probably synchronous with cold and dry climatic conditions (Hubschman, 1975; Ivy-Ochs et al., 2009). There are no dates for the innermost moraine system MS-4 composed of two moraine ridges left by the glacier in its retreat. Their morphostratigraphic position suggests their deposition after the LGM and before the Bølling-Allerød period. Two cold periods were inferred from the sequence of Lake Barbazan, indicated by the diminishing $\delta^{18} \mathrm{O}$; they were dated at between 18.2 and 19 and $21.1 \mathrm{ka}$ cal BP, which may have generated these two moraines. In the Ariège basin, two retreat moraines of a similar strength and at the same distance from the MIE moraine $(6-7 \mathrm{~km})$ were dated at 18.8 and $19.1 \mathrm{ka}$ (Delmas et al., 2011; Calvet et al., 2011). By the Bølling-Allerød period, the LouresBarousse-Barbazan basin was ice-free as revealed by the presence of a fluvial terrace in the middle of the basin (14.6 ka cal BP; Stange et al., 2014) and the dating of organic sediments of Lake Barbazan, which suggests moderately warm conditions around $15 \mathrm{ka}$ cal BP (Andrieu et al., 1993).

Stage 2 is composed of moraine complexes between 1000 and $1850 \mathrm{~m}$, at between 23 and $12 \mathrm{~km}$ from the head. The external complex of stage 2 is situated inside the valley and was formed during a period of glacier stability within the long-term deglaciation process in the Garonne River. Inferred paleotemperatures for that period at the highest elevations were ca. $-3.3^{\circ} \mathrm{C}$. This phase may be related to the Oldest Dryas (17.5-14.5 ka), the first cold period after the MIE able to generate moraines of such magnitude, as observed in other basins in the Pyrenees, where Oldest Dryas moraines dated between 17 and $14.4 \mathrm{ka}$ are located inside the valleys at similar altitudes and distances from the heads (Pallàs et al., 2010; Delmas et al., 2011; Palacios et al., 2015a, 2015b, 2016b). In the tributaries of the Garonne, Bordonau (1985) and Martí-Soler (1988) identified moraine deposits at $1460 \mathrm{~m}$ (Nere) and between 1360 and $2000 \mathrm{~m}$ (Joeu) and 1800-2000 (Unhòla and Varradòs) and attributed them to the Oldest Dryas. A similar chronology was inferred on the southern slopes of the Pyrenees, in the Gállego valley, where a moraine complex was dated at 15.5 ka (Palacios et al., 2015a). In other Iberian mountains there are also local glacial records of the Oldest Dryas, as occurs in the Gredos and Guadarrama massifs (Central System) (Palacios et al., 2012a, 2012b) and in the Sierra Nevada (Palacios et al., 2016a).

Stage 3 is defined by a sequence of moraines situated at altitudes of 2050-2200 $\mathrm{m}$. In stage 3 the glacier abandoned the bottom of the main valley of the Garonne basin, but glaciers remained within the valleys of its tributaries, as happened in the Beret plateau and in the Ruda valley, where glaciers were 4.5 and $2.6 \mathrm{~km}$ long, respectively. The well-preserved frontal and lateral-frontal moraines of Beret and Ruda are distributed at elevations between 1850 and $1900 \mathrm{~m}$ and 2050-2200 m, respectively. The lower altitudes of Beret moraines may be related to the topographical arrangement of the Bacivèr massif as a funnel that channelled the glacier from the wide area beside the glacial cirques to a narrow, steep area along the Malo River ending in a completely flat area in Beret. Paleotemperatures during that phase at the highest lands were ca. $-2.8{ }^{\circ} \mathrm{C}$. Despite not having absolute dates for this stage, García-Ruiz et al. (2016) identified the formation of glaciers of similar extents $(\sim 4-6 \mathrm{~km})$ in the Central Pyrenees during the Younger Dryas (12.9-11.7 ka), which may correspond to this stage in the Garonne basin (Table 1). In the Eastern Pyrenees a period of glacier advance was also recorded inside the cirques or near their limits between 11.6 and 12.8 ka (Delmas et al., 2008; Pallàs et al., 2006, 2010; Palacios et al., 2015b), as also occurred in the Sierra Nevada (Palacios et al., 2016a).

The final stage 4 corresponds to glaciers already circumscribed inside the glacial cirques, where they generated frontal moraines at altitudes of $2160-2590 \mathrm{~m}$, and glaciers between 2.3 and $0.23 \mathrm{~km}$ long from the cirque walls. Bordonau (1985) and Martí-Soler (1988) identified this stage in the Nere, Joeu, Unhòla, Varradòs and Toran valleys. The fact of being located at higher elevations than the moraines formed during the last Pleistocene cold crises suggests that they must have developed during the coldest and wettest stages of the Holocene. Temperatures during this period at the highest lands were ca. $-2.4^{\circ} \mathrm{C}$. In the Monte Perdido massif, 500 m above the heads of Ruda, García-Ruiz et al. (2014) dated a moraine cirque system at $5.1 \mathrm{ka}$. Holocene glacier advances were also inferred in the Mulhacén cirque, in the Sierra Nevada, during the coldest stages of the early Holocene (Oliva and Gómez-Ortiz, 2012). There were no glaciers during the LIA in the upper Garonne valley, since the cirques are located at elevations 200-400 m lower than the massifs glaciated during the LIA in the Pyrenees (González-Trueba et al., 2008).

\subsection{Postglacial environmental dynamics in the upper Garonne valley}

The analysis of the distribution of landforms and processes in the Ruda valley and on the Beret plateau allow inference of post-glacial environmental evolution in the upper Garonne valley since the last Pleistocene glacier cycle. The environmental dynamics are today organized in elevation belts that have a morphogenesis similar to other mountain environments in the Iberian Peninsula. Based on the typology and intensity of geomorphological processes and the associated geoecological dynamics, the study area is divided in three domains: subnival (1500$1900 \mathrm{~m}$ ), nival (1900-2300 m) and periglacial or cryonival (23002800 m) (Fig. 14; Table 2).

\subsubsection{Sub-nival domain (1500-1900 m)}

The sub-nival domain is composed of inherited and current landforms of diverse origins associated with glacial, periglacial and alluvial/fluvial dynamics. In the valley bottom, the retreating glaciers deposited till among the moraine complexes generated during stage 2 . Subsequently, glacio-fluvial and fluvial dynamics have gradually eroded these till layers. Polished surfaces exposed following the glacier's retreat are today partially occupied by forests of Pinus nigra. Periglacial dynamics intensified in these areas during the paraglacial stage, as also occurred in other Iberian mountain ranges during the Bølling-Allerød period (Oliva et al., 2016). After the glacier's retreat, there is a rise in 


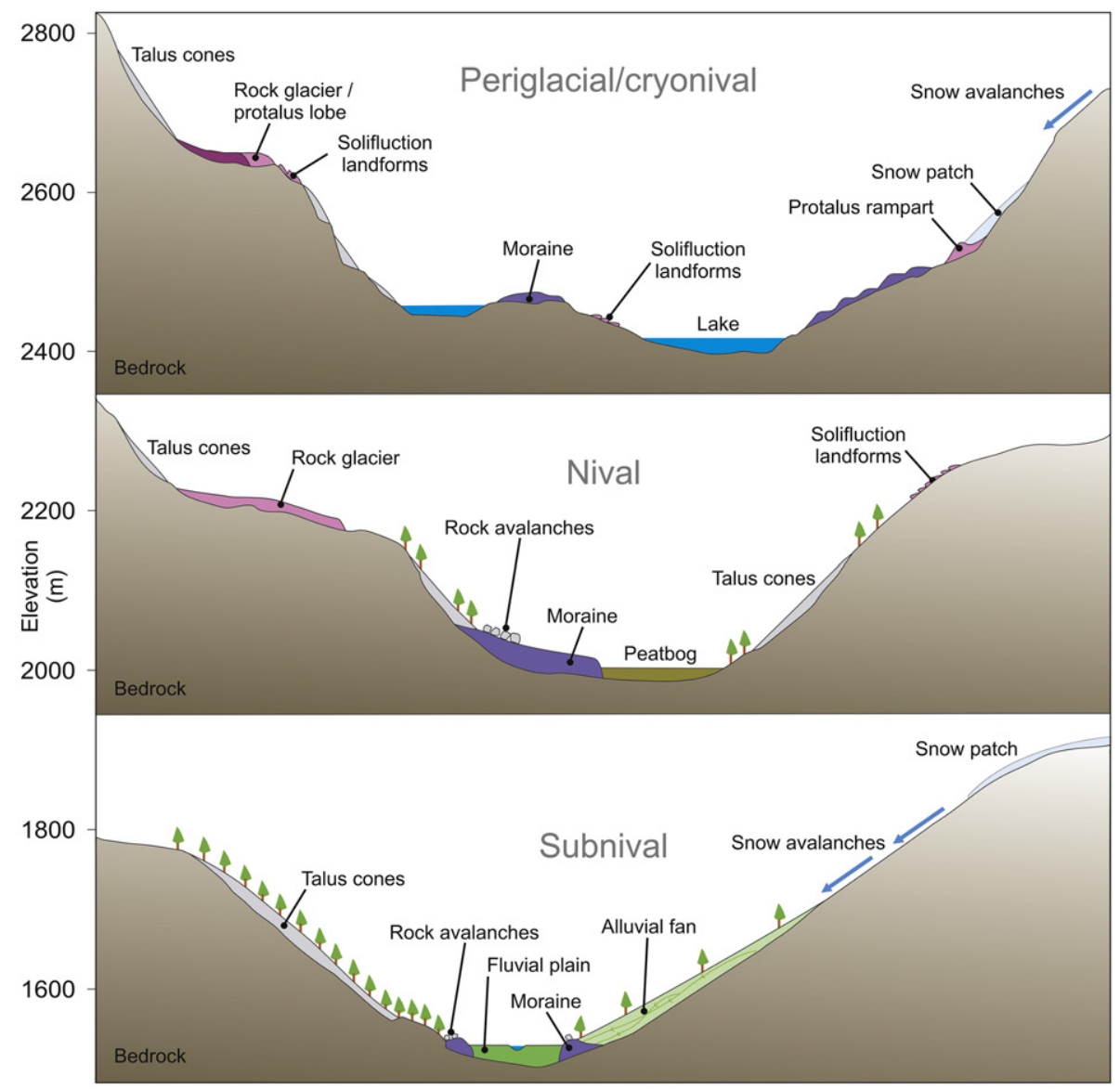

Fig. 14. Sketch of the elevation belts of geomorphic landforms and processes in the upper Garonne basin.

the height of the periglacial domain; the slopes freed from the pressure exerted by the glaciers were consequently exposed to physical weathering processes and covered with detritus. The warming recorded at the onset of the Holocene in the Pyrenees determined the abandonment of the periglacial belt to altitudes above $2500 \mathrm{~m}$ (García-Ruiz et al., 2005). The depositing of debris on the slopes below $2000 \mathrm{~m}$ was dated to the Bølling-Allerød age in the Cinca valley, Central Pyrenees (García-Ruiz et al., 2001). Nowadays, organic soils and forests colonize these debris slopes with prevailing geomorphic stability, except in the areas affected by fluvial, alluvial, and seasonally nival dynamics. Alluvial fans from this environment are a consequence of a mixed geomorphic dynamics (alluvial + avalanches). They are distributed at the exit of the mountain ravines, which during the thaw season can mobilize the sediments covering the slopes and even damage the forests. This pattern is reinforced by the avalanches descending from the upper nival domain from November to May, when the ground is snow covered.

\subsubsection{Nival domain (1900-2300 m)}

The nival domain is located between the sub-nival domain and the periglacial environment. Geomorphological features encompass inactive landforms of glacial and periglacial origin, together with active landforms originated by nival dynamics and the presence of seasonal ground ice. In the overdeepened glacial basins existing in the Ruda valley, glacial dynamics prevailed probably during the Younger Dryas, with the development of stage 3 moraines (2050-2200 m). In the highest parts of this domain there are the lowest glacial cirques that were deglaciated between the MIE and the Oldest Dryas. These areas were subsequently affected by periglacial activity, forming rock glaciers and protalus lobes, as also happened in other Iberian mountain ranges during this period (Andrés et al., 2015; Palacios et al., 2015b; Oliva et al., 2016). Post-glacial environmental dynamics in overdeepened glacial basins and polished surfaces favored soil development, and the vegetal colonization of alpine meadows, peat and some Pinus nigra in lower elevations. This dynamics, initiated during the Younger Dryas, continued and was reinforced throughout the Holocene. Glacial retreat also exposed slopes to periglacial dynamics, where mechanical weathering formed debris slopes and talus cones, which are more frequent than in the sub-nival domain. Today, these units are partially colonized by lichens and very occasionally by alpine meadows, which suggests that they are still active. Present-day processes in this domain are highly influenced by the intensity and duration of the seasonal snow cover. In turn, snow also controls mass movements on the slopes, such as

Table 2

Distribution of active geomorphological processes today in the upper Garonne basin.

\begin{tabular}{|c|c|c|c|}
\hline Domain & Environment & Processes & Landforms \\
\hline Subnival & $\begin{array}{l}\text { Valley bottoms and surrounding slopes } \\
(1500-1900 \mathrm{~m})\end{array}$ & $\begin{array}{l}\text { Fluvial activity, peat development, soil formation, avalanches, } \\
\text { debris flows }\end{array}$ & $\begin{array}{l}\text { Fluvial plain, peatlands, alluvial fans, talus } \\
\text { slopes }\end{array}$ \\
\hline Nival & $\begin{array}{l}\text { Overdeepened glacial basins and } \\
\text { surrounding slopes (1900-2300 m) }\end{array}$ & $\begin{array}{l}\text { Incipient soil formation, avalanches, debris flows, } \\
\text { cryoturbation, mechanical weathering, solifluction }\end{array}$ & $\begin{array}{l}\text { Talus cones, talus slopes, solifluction } \\
\text { landforms }\end{array}$ \\
\hline Periglacial/cryonival & $\begin{array}{l}\text { Glacial cirques, peaks and rocky ridges } \\
(2300-2800 \mathrm{~m})\end{array}$ & $\begin{array}{l}\text { Incipient soil formation, avalanches, debris flows, } \\
\text { cryoturbation, mechanical weathering, solifluction }\end{array}$ & $\begin{array}{l}\text { Talus cones, talus slopes, solifluction } \\
\text { landforms, protalus ramparts }\end{array}$ \\
\hline
\end{tabular}


avalanches, alluvial fans, and vegetated slopes affected by solifluction that form decimetric terracettes (Fig. 13).

\subsubsection{Periglacial/cryonival domain (2300-2800 m)}

The periglacial or cryonival domain is situated between $2300 \mathrm{~m}$ and the tops of the peaks over $2800 \mathrm{~m}$. This belt includes glacial inherited features as well as active and inactive periglacial phenomena. Above $2300 \mathrm{~m}$, the periglacial environment is composed of scarce alpine meadows with fine, young poorly-developed soils affected by cryogenic processes such as solifluction landforms in areas with moderate to steep slopes $\left(>15^{\circ}\right)$ and mostly facing north. On the slopes, evidence of (sub)current debris flows are present, which probably originated during the thaw period when the superficial formation becomes saturated still in the presence of sub-superficially frozen soil (Oliva et al., 2009). Inside the highest glacial cirques and hollows, frontal moraines formed during stage 4 are found, probably originated during the coldest Holocene stages. The retreat of these cirque glaciers exposed polished surfaces and environments today occupied by meadows and fine organic soils. During this stage, there is a migration of the periglacial environment to higher elevations. The ice-free rock walls were subsequently affected by freeze-thaw action, generating abundant talus cones. Both the moraine and these deposits were affected by creeping processes that created a new generation of rock glaciers or protalus lobes, next to the cirque walls (Andrés et al., 2015). These landforms are indicators of permafrost and probably ceased to be active during the Middle and Late Holocene (Serrano and Agudo, 2004). These landforms, together with protalus ramparts, are particularly well-developed in the Bacivèr massif, in some cases forming transitional landforms which are characteristic of glacionival dynamics. In the case of protalus ramparts, they are still active today, as suggested by the non-existence of lichens and vegetation on their surface.

\section{Conclusions}

This research aimed to deepen knowledge about glacial evolution in the upper Garonne basin, Central Pyrenees, during the last Pleistocene cold cycle as well as its subsequent environmental evolution, namely in the Ruda valley and Beret plateau. At present, the landscape of this area is the consequence of the geomorphological footprint left by the glaciers during the Last Glaciation and its subsequent reworking by slope, nival and alluvial periglacial activity.

From the morphostratigraphic relationships between the forms and glacial and periglacial deposits, as well as the comparison with existing studies with absolute dates for the Central Pyrenees, we can infer a relative chronology for each of the four stages indicated in the sequence of the glacial retreat in the upper Garonne valley:

- Stage 1: valley and piedmont glaciers, which correspond to the MIE with glaciers reaching $88.7 \mathrm{~km}$ in length and $960 \mathrm{~km}^{2}$ of glacial extent, possibly associated with MIS-2.

- Stage 2: valley glaciers, with glaciers between 12 and $23 \mathrm{~km}$ in length and $157 \mathrm{~km}^{2}$ of glacial surface. This stage seems to correspond to the Oldest Dryas.

- Stage 3: glaciers in the high parts of the valleys or on the plateaus, with isolated glaciers of $2.6-4.5 \mathrm{~km}$ in length and a glacial surface of $16 \mathrm{~km}^{2}$. This stage presents an extent of the glaciers comparable to that occurring in other areas of the Central Pyrenees during the Younger Dryas.

- Stage 4: cirque glaciers, covering a surface of $5.7 \mathrm{~km}^{2}$ and not extending beyond $2 \mathrm{~km}$ in length. This last stage of deglaciation seems to be associated with cold periods in the Holocene.

The distribution of current geomorphological landforms and processes in the higher parts of the upper Garonne basin lets us infer the post-glacial environmental evolution and their current elevation zoning in three domains: sub-nival, nival and periglacial. The sub-nival domain is situated on the valley floor and surrounding slopes, between 1500 and $1900 \mathrm{~m}$, where a forest environment with well-developed soils prevails, and with the current predominance of fluvial, alluvial and slope processes, seasonally affected by nival dynamics (avalanches). The nival domain, including the glacial overdeepened depressions and surrounding slopes between 1900 and $2300 \mathrm{~m}$, is an environment where nival processes develop, with less dense forests and increased alpine meadow and rocky surfaces. Finally, the periglacial level is found in the cirques and slopes between 2300 and $2800 \mathrm{~m}$, where current environmental dynamics are characterized by cryogenic processes with intense geomorphic activity derived from freeze-thaw cycles. Intense cryoturbation and solifluction activity determine a sparse vegetation cover and weak soil formation.

Future research will provide the chronological time frame for the four glacial stages identified from the erosional and depositional landforms existing in the upper Garonne basin, besides determining the ages of the landforms of periglacial origin existing in the highest parts of the study area.

\section{Acknowledgements}

This research has been funded by the Research Group Climate Change and Environmental Systems (ZEPHYRUS) of the Institute of Geography and Spatial Planning of the University of Lisbon. This research was supported by the project CTM2016-77878-P.

\section{References}

Allen, R., Siegert, M.J., Payne, A.J., 2008. Reconstructing glacier-based climates of LGM Europe and Russia - part 2: a dataset of LGM precipitation/temperature relations derived from degree-day modelling of palaeo glaciers. Clim. Past 4, 249-263.

Andrés, N., Palacios, D., Gómez-Ortiz, A., García-Ruiz, J.M., López-Moreno, J.I., SalvadorFranch, F., Oliva, M., 2015. Origen, cronología y evolución de los glaciares rocosos fósiles de las cordilleras ibéricas (Pirineos, Sistema Central y Sierra Nevada). In: Serrano, E. (Ed.), Proceedings of the V Iberian Conference of the International Permafrost Association, Valladolid (Spain) (35 pp).

Andrieu, V., 1991. Dynamique du paléoenvironnement de la vallée montagnarde de la Garonne (Pyrénées centrales, France) de la fin des temp glaciaires à l'actuel. (PhD thesis). University of Toulouse, France.

Andrieu, V., Hubschman, J., Jalut, G., Hérail, G., 1988. Chronologie de la dégladation des Pyrénées françaises. Dynamique de sédimentation et contenu pollinique des paléolacs; application à l'interprétation du retrait glaciaire. Bulletin de l'Association française pour l'étude du quaternaire. 25 (2-3), pp. 55-67.

Andrieu, V., Eicher, U., Reille, M., 1993. La fin de dernier Pléniglaciaire dans les Pyrénées (France): données polliniques, isotopiques et radiométriques. Comptes Rendus de l'Académie des Sciences Paris 316 (II), 245-250.

Barr, L.D., Spagnolo, M., 2015. Glacial cirques as palaeoenvironmental indicators: their potential and limitations. Earth Sci. Rev. 151, 48-78.

Bolòs, O., Vigo, J., 1984. Flora dels Països Catalans. Editorial Barcino, Barcelona.

Bordonau, J., 1985. Estudi geomorfològic del sector sudoccidental de la Vall d'Aran. L'evolución quaternária de les valls dels rius Joeu i Nere. University of Barcelona, Spain (Bacherlor thesis).

Bordonau, J., 1992. Els complexos glàcio-lacustres relacionats amb el darrer cicle glacial als Pirineus. (PhD thesis). University of Barcelona, Spain.

Calvet, M., Delmas, M. Gunnel, Y., Braucher, R., Bourlès, D, 2011. Recent advances in research on Quaternary glaciations in the Pyrenees. In: Ehlers, J., Gibbard, P.L. (Eds.), Quaternary Glaciations, Extent and Chronology, A Closer Look. Part IV. Elsevier, Amsterdam, pp. 127-139.

Delmas, M., 2009. Chronologie et impact géomorphologique des glaciations quaternaires dans l'est des Pyrénées. (PhD thesis). Université de Paris 1 Panthéon-Sorbonne, pp. 7-29.

Delmas, M., 2015. The last maximum ice extent and subsequent deglaciation of the Pyrenees: an overview of recent research. Cuadernos de Investigación Geográfica 41 (2), 359-387.

Delmas, M., Gunnell, Y., Braucher, R., Calvet, M., Bourlès, D., 2008. Exposure age chronology of the last glacial cycle in the eastern Pyrenees. Quat. Res. 69 (2), 231-241.

Delmas, M., Calvet, M., Gunnell, M., Braucher, R., Bourlès, D., 2011. Palaeogeography and ${ }^{10}$ Be exposure-age chronology of Middle and Late Pleistocene glacier systems in the northern Pyrenees: implications for reconstructing regional palaeoclimates. Palaeogeogr. Palaeoclimatol. Palaeoecol. 305, 109-122.

García-Ruiz, J.M., Martí-Bono, C., 2011. Los depósitos glaciares del valle del Aragón Subordán, Pirineo Centro-occidental español. Cuaternario y Geomorfología. 25, pp. $57-81$.

García-Ruiz, J.M., Valero-Garcés, B.L., González-Sampériz, P., Lorente, A., Martí Bono, C., Beguería, S., Edwards, L., 2001. Stratified scree in the Central Spanish Pyrenees: palaeoenvironmental implications. Permafr. Periglac. Process. 12, 233-242. 
García-Ruiz, J.M., Valero Garcés, B., Martí Bono, C., González Sampériz, P., 2003. Asynchroneity of maximum glacier advances in the central Spanish Pyrenees. J. Quat. Sci. 18 (1), 61-72.

García-Ruiz, J.M., Martí Bono, C., Valero, B., Gonzalez-Samperiz, P., 2005. Central Spanish Pyrenees: glacial and periglacial landforms. Field Trip 8. Sixth International Conference on Geomorphology, Field Trip Guides t-1. SEG-University of Zaragoza, pp. 311-340.

García-Ruiz, J.M., Moreno, A., González-Sampériz, P., Valero-Garcés, B., Martí-Bono, C. 2010. La cronología del último ciclo glaciar en las montañas del sur de Europa. In: Una revisión (Ed.), Cuaternario y Geomorfología. 24, pp. 35-46.

García-Ruiz, J.M., Martí-Bono, C., Peña-Monné Sancho, C., Rhodes, R.J., Valero-Garcés, González-Sampériz, P., Moreno, A., 2013. Glacial and fluvial deposits in the Aragon Valley, Central-Western Pyrenees: chronology of the Pyrenean Late Pleistocene Glaciers. Geogr. Ann. Ser. A 95, 15-32.

García-Ruiz, J.M., Palacios, D., Andrés, N., Valero-Garcés, B.L., López-Moreno, J.I., Sanjuán, Y., 2014. Holocene and 'little ice age' glacial activity in the Marboré cirque, Monte Perdido Massif, Central Spanish Pyrenees. The Holocene 24 (11), 1439-1452.

García-Ruiz, J.M., López-Moreno, J.I., Lasanta, T., Vicente Serrano, M., González-Sampériz, P., Valero-Garcés, B.L., Sanjuán, Y., Beguería, S., Nadal-Romero, E., Lana-Renault, N., Gómez-Villar, G., 2015. Los efectos geoecológicos del cambio global en elpirineo central español: una revisión a distintas escalas espaciales y temporales. Pirineos 170.

García-Ruiz, J.M., Palacios, D., González-Sampériz, P., Andrés, N., Moreno, A., ValeroGarcés, B., Gómez-Villar, A., 2016. Mountain glacier evolution in the Iberian Peninsula during the Younger Dryas. Quat. Sci. Rev. 138, 16-30.

Gómez-Ortiz, A., Oliva, M., Salvà-Catarineu, M., Salvador-Franch, F., 2013. The environmental protection of landscapes in the high semiarid Mediterranean mountain of Sierra Nevada National Park (Spain): historical evolution and future perspectives. Appl. Geogr. 42, 227-239.

González-Trueba, J.J., Martín-Moreno, R., Martínez de Pisón, E., Serrano, E., 2008. Little ice age glacier advance and current glaciers in the Iberian Peninsula. The Holocene 18, 551-568.

Goron, L., 1941. Le rolê des glaciations quaternaires dens modeló des vallées maitresses des pre-pyrénées ariégoises et garonnaises et de leur avant-pays. (PhD thesis). University of Toulouse, France.

Herail, G., Jalut, G., 1986. L'obturation de Sost (haute Garone): données nouveles sur le paléoenvironnement de la phase glacier wurmien dans les Pyrénées centrales. C. R. Acad. Sci. 303 (2, 8), 743-748.

Höllermann, P., 1985. The periglacial belt of mid-latitude mountains from a geoecological point of view. Erdkunde 39 (4), 259-270.

Hubschman, J., 1975. La plaine de rivière et le complexe de terrasses et moraines au Sud de Montrejeau. Bulletin de l'Association Française pour l'Etude du Quaternaire. 12 (3-4), pp. 192-200.

Hubschman, J., 1984. Glaciaire ancien et glaciaire récent: analyse comparée de l'altération de moraines terminals nord-pyrénéennes. Colloque «Montagnes-Piémonts», Revue Géographique des Pyrénées et du Sud-Ouest. I, pp. 313-332.

Hughes, P.D., Woodward, J.C., 2008. Timing of glaciation in the Mediterranean mountains during the last cold stage. J. Quat. Sci. 23 (6-7), 575-588.

Ivy-Ochs, S., Kerschner, H., Maisch, M., Christl, M., Kubik, P.W., 2009. Latest Pleistocene and Holocene glacier variations in the European Alps. Quat. Sci. Rev. 28, 2137-2149.

Jiménez-Sánchez, M., Rodríguez-Rodríguez, L., García-Ruiz, J.M., Domínguez-Cuesta, M.J. Fariasa, P., Valero-Garcés, B., Moreno, A., Ricob, M., Valcárcel, M., 2013. A review of glacial geomorphology and chronology in northern Spain: timing and regional variability during the last glacial cycle. Geomorphology 196, 50-64.

Joly, F., 1997. Glossaire de géomorphologie. Base de donnés sémiologiques pour la cartographie. Masson/Armand Colin, Paris.

Kleinsmiede, W.F.J., 1960. Geology of the Valle d'Aran (Central Pyrenees). Leidse. Geol. Meded. 25, 129-245.

Lasanta, T., Beguería, S., García-Ruiz, J.M., 2006. Geomorphic and hydrological effects of traditional shifting agriculture in a Mediterranean mountain area, Central Spanish Pyrenees. Mt. Res. Dev. 26 (2), 146-152.

Lewis, C.J., McDonald, E.V., Sancho, C., 2009. Climatic implications of correlated Upper Pleistocene glacial and fluvial deposits on the Cinca and Gállego rivers (NE Spain) based on OSL dating and soil stratigraphy. Glob. Planet. Chang. 67, 141-152.

Mardones, M., Jalut, G., 1983. La tourbière de Biscaye (alt. 409 m, Hauter Pyrénées): aproche paléoécologuique des 45,000 dernières années. Pollen Spores 25, 163-211.

Martín-Vide, J., Brunet, M., Prohom, M., Rius, A., 2011. Els climes de Catalunya. Present i tendències recents. In: Llebot, J.E. (Ed.), Segon informe sobre el canvi climàtic a Catalunya. Institut d'Estudis Catalans i Generalitat de Catalunya, pp. 39-72.

Martí-Soler, M., 1988. Estudi geomorfològic del massis central de la Vall d'Aran (Pirineu Central). (Bachelor thesis). University of Barcelona, Spain.

Mianes, A., 1955. Les Ancienes glaciers des pyrénées garonnaises. Pirineos XI (35-38), 5-76.

Nieuwendam, A., Ruiz-Fernández, J., Oliva, M., Freitas, C., Paio, V., Cruces, A., 2015. Postglacial landscape changes and cryogenic processes in the Picos de Europa (Northern Spain) reconstructed from geomorphological mapping and microstructures on quartz grains. Permafr. Periglac. Process. 27, 96-108.

Oliva, M., Gómez-Ortiz, A., 2012. Late Holocene environmental dynamics and climate variability in a Mediterranean high mountain environment (Sierra Nevada, Spain) inferred from lake sediments and historical sources. The Holocene 22 (8), 915-927.

Oliva, M., Gómez Ortiz, A., Schulte, L., Salvador-Franch, F., 2009. Procesos periglaciares actuales en Sierra Nevada. Distribución y morfometría de los lóbulos de solifluxión en los altos valles nevadenses. Nimbus 23-24, 133-148.

Oliva, M., Serrano, E., Gomez-Ortiz, A., González-Amuchastegui, M.J., Nieuwendam, A., Palacios, D., Pérez-Alberti, A., Pellitero-Ondicol, R., Ruiz-Fernández, J., Valcárcel, M., Vieira, G., Antoniades, D., 2016. Spatial and temporal variability of periglaciation of the Iberian Peninsula. Quat. Sci. Rev. 137, 176-199.
Palacios, D., Andrés, N., Marcosa, J., Vázquez-Selemc, L., 2012a. Glacial landforms and their paleoclimatic significance in Sierra de Guadarrama, Central Iberian Peninsula. Geomorphology 139-140, 67-78.

Palacios, D., Andrés, N., Marcos, J., Vázquez-Selem, L., 2012b. Maximum glacial advance and deglaciation of the Pinar Valley (Sierra de Gredos, Central Spain) and its significance in the Mediterranean context. Geomorphology 177-178, 51-61.

Palacios, D., Andrés, N., López-Moreno, J., García-Ruiz, J., 2015a. Late Pleistocene deglaciation in the upper Gállego Valley, Central Pyrenees. Quat. Res. 83, 397-414.

Palacios, D., Gómez-Ortiz, A., Andrés, N., Vázquez-Selem, L., Salvador-Franch, F., Oliva, M. 2015b. Maximum extent of Late Pleistocene glaciers and last deglaciation La Cerdanya montains, Southeastern Pyrenees. Geomorphology 231, 116-129.

Palacios, D., Gómez-Ortiz, A., Andres, N., Salvador, F., Oliva, M., 2016a. Timing and new geomorphologic evidence of the last deglaciation stages in Sierra Nevada (southern Spain). Quat. Sci. Rev. 150, 110-129.

Palacios, D., de Andrés, N., Gómez-Ortiz, A., García-Ruiz, J.M., 2016b. Evidence of glacial activity during the Oldest Dryas in the mountains of Spain. In: Hughes, P.D. Woodward, J.C. (Eds.), Quaternary Glaciation in the Mediterranean MountainsSpecial Publications 433. Geological Society, London. http://dx.doi.org/10.1144/SP433.10.

Pallàs, R., Rodés, A., Braucher, R., Carcaillet, J., Ortuno, M., Bordonaua, J., Bourlès, D. Vilaplana, J.M., Masana, E., Santanach, P., 2006. Late Pleistocene and Holocene glaciation in the Pyrenees: a critical review and new evidence from ${ }^{10}$ Be exposure ages, south-central Pyrenees. Quat. Sci. Rev. 25 (21-22), 2937-2963.

Pallàs, R., Rodés, A., Braucher, R., Bourlès, D., Delmas, M., Calvet, M., Gunnell, Y., 2010. Small, isolated glacial catchments as priority target for cosmogenic surface dating of Pleistocene climate fluctuations, SE Pyrenees. Geology 38, 891-894.

Pellitero, R., Rea, B., Spagnolo, M., Bakke, J., Hughes, F., Ivy-Ochs, S., Lukas, S., Ribolini, A. 2015. A GIS tool for automatic calculation of glacier equilibrium-line altitudes. Comput. Geosci. 82, 55-62.

Pellitero, R., Rea, R.B., Spagnol, M., Bakke, J., Ivy-Ochs, S., Frew, R.C., Hughes, P., Ribolini, A Lukas, S., Renssen, A., 2016. GlaRe, a GIS tool to reconstruct the 3D surface of palaeoglaciers. Comput. Geosci. 94, 77-85.

Peña, J.L., Sancho, C., Lewis, C., McDonald, E., Rhodes, E., 2004. Datos cronológicos de las morrenas terminales del glaciar del Gállego y su relación con las terrazas fluvioglaciares (Pirineo de Huesca). In: Peña, J.L., Longares, L.A., Sánchez, M. (Eds.), Geografía Física de Aragón, Aspectos generales y temáticos. Universidad de Zaragoza e Institución Fernando el Católico, Zaragoza, pp. 71-84.

Peña-Monné, J.L., Sancho, C., Lewis, C., McDonald, E., Rhodes, E., 2003. Las morrenas terminales de los valles glaciares del Gállego y Cinca (Pirineo de Huesca). Datos cronológicos. Boletín Glaciológico Aragonés 4, 91-109.

Penck, A., 1883. Die Eiszeit in der Pyrenâen. Mitteilungen des Vereins fur Erdkunde, Leipzig, 163-231. Franch tradution of L. Braemer., 1885: La période glaciaire dans les Pyrénées, Bulletin de la Société d'Histoire Naturelle de Toulouse. XIX pp. 105-200.

Pérez-Alberti, A., Valcárcel, D.M., Blanco-Chao, R., 2004. Pleistocene glaciation in Spain. In: Ehlers, J., Gibbard, P.L. (Eds.), Quaternary Glaciations - Extent and Chronology. Elsevier, Amsterdam, pp. 389-394.

Pérez-Sanz, A., González-Sampériz, P., Moreno, A., Valero-Garcés, B., Gil-Romera, G. Rieradevall, M., Tarrats, P., Lasheras-Álvarez, L., Morellón, M., Belmonte, A., Sancho, C., Sevilla-Callejo, M., Navas, A., 2013. Holocene climate variability, vegetation dynamics and fire regime in the central Pyrenees: the Basa de la Mora sequence (NE Spain). Quat. Sci. Rev. 73, 149-169.

Porter, S.C., 2000. Snowline depression in the tropics during the Last Glaciation. Quat. Sci. Rev. 20 (10), 1067-1091

Reimer, P.J., Bard, E., Bayliss, A., Beck, J.W., Blackwell, P.G., Bronk Ramsey, C., Buck, C.E., Edwards, R.L., Friedrich, M., Grootes, P.M., Guilderson, T.P., Haflidason, H., Hajdas, I. Hatté, C., Heaton, T.J., Hoffmann, D.L., Hogg, A.G., Hughen, K.A., Kaiser, K.F., Kromer B., Manning, S.W., Niu, M., Reimer, R.W., Richards, D.A., Scott, E.M., Southon, J.R., Staff, R.A., Turney, S.M., van der Plicht, J., 2013. Intcall3 and marine13 radiocarbon age calibration curves 0-50,000 years cal BP. Radiocarbon 55, 1869-1887.

Ruiz-Fernández, J., Oliva, M., Cruces, A., Lopes, V., Freitas, M.C., Andrade, C., GarcíaHernández, C., López-Sáez, J.A., Geraldes, M., 2016a. Environmental evolution in the Picos de Europa (Cantabrian Mountains, SW Europe) since the Last Glaciation. Quat. Sci. Rev. 138, 87-104.

Ruiz-Fernández, J., Nieuwendam, A., Oliva, M., Lopes, V., Cruces, A., Freitas, M.C. Janeiro, A.I., López-Sáez, J.A., 2016b. Cryogenic processes and fire activity in a high Atlantic mountain area in NW Iberia (Picos de Europa) during the Mid-Late Holocene. Sience of the Total Environment http://dx.doi.org/10.1016/j.scitotenv. 2016.03.022.

Serrano, E., Agudo, C., 2004. Glaciares rocosos y deglaciación en la alta montaña de los Pirineos aragoneses (España). Boletín de la Real Sociedad Española de Historia Natura (Sección Geológica) 99, 159-172.

Serrano-Muela, M.P., Lana-Renault, N., Nadal-Romero, E., Regüés, D., Latron, J., MartíBono, C., García-Ruiz, J.M., 2008. Forests and their hydrological effects in Mediterranean mountains: the case of the Central Spanish Pyrenees. Mt. Res. Dev. 28 (3-4) 279-285.

Serrat, D., Martí, M., Bordunau, J., 1994. Geologia, Geomofologia e Risques, em: Geografia Física, em: Atlas comarcau de Catalunya-Val d'Aran. Institut Cartogràfic de Catalunya. Generalitat de Catalunya.

Stange, K.M., Van Balen, R.T., Kasse, C., Vandenberghe, J., Carcaillet, J., 2014. Linking morphology across the glaciofluvial interface: a ${ }^{10} \mathrm{Be}$ supported chronology of glacier advances and terrace formation in the Garonne River, northern Pyrenees, France. Geomorphology 207, 71-95.

Taillefer, F., 1954. La terminaison du Glacier de la Garonne au sud de Montréjeau Bulletin de la Section de Géographie, Comité des Travaux Historiques et Scientifiques., t. LXVI (actes du 78 ème Congrès des Sociétés savantes, Toulouse) (271-282 pp).

Taillefer, F., 1957. Le glaciaire pyrénéen: versant nord et versant sud. Revue Géographique des Pyrénées et du Sud-Ouest XXVIII (3), 221-244. 
Taillefer, F., 1969. Terrasses de la vallée souspyrénéenne de la Neste-Garonne et morphologie glaciaire de la vallée de la Garonne. Le Quaternaire de la vallée de l'Ariège. Livret-guide excursion A 6, VIII Congrès INQUA, Paris, pp. 38-47.

Taillefer, F., 1984. La terminaison du glacier de la Garonne au sud de Montréjeau. Bulletin de la Section de Géographie 66. Comité des Travaux Historiques et Scientifiques, pp. 271-282.

Turu, V., Calvet, M., Bordonau, J., Gunnell, Y., Delmas, M., Vilaplana, J.M., Jalut, G., 2016. Did Pyrenean glaciers dance to the beat of global climatic events? Evidence from the
Wurmian sequence stratigraphy of an ice-dammed palaeolake depocentre in Andorra. In: Hughes, P.D., Woodward, J.C. (Eds.), Quaternary Glaciation in the Mediterranean Mountains. Geological Society, London, Special Publications (433 pp).

Vilaplana, J.M., Serrat, D., Bordonau, J., 1986. Formaciones sedimentarias cuaternarias de origen glaciar en el Pirineo: tills, sediments glaciolacustres y sedimentos glaciofluviales. In: Anadón, P., Cabrera, L. (Eds.), Guía de las excursiones del XI Congreso Español de Sedimentología, Barcelona (294 pp). 